\title{
Politics, Technology, and Accountability: The Transparency Façade of Open Government Data Reforms in Paraguay
}

\section{David Riveros García}

reAcción Paraguay, david@reaccion.org.py

\begin{abstract}
Governments have adopted the rhetoric of promoting transparency, citizen engagement, and accountability through technological innovation. The provision of open government data has been encouraged as a foundational reform in that direction. This study argues that, in Paraguay's education sector, these reforms were never capable of matching said rhetoric. Using a case study design, the research shows that the stated goals of intuitively simplifying information to facilitate citizen monitoring of funds for education infrastructure were never realistically attempted by the government. It will advocate the relevance of considering the relationship between politics, accountability, and technology to uncover transparency façades.
\end{abstract}

Keywords: Open Government Data, Collective Action, Accountability, Education, Infrastructure

Acknowledgement: I wish to thank the volunteers from the ParaguaYOite and AIGA teams at reAcción for giving their time and effort to collect and digitize data that was essential for this research.

\section{Introduction}

Governments govern better and are more legitimate when they listen to their citizens. The pace of technological developments has made this maxim as simple as the creation of mobile applications. Citizens currently use them to provide feedback on almost anything imaginable. However, a gap exists in terms of the benefits of an internet-connected world. The rate of technological innovation has far outpaced that of bureaucratic institutional adaptation. This relates to the processes that guide and sustain peaceful coexistence in democracies, but also to the modern state's capacity to adapt to the pressures and exploit the opportunities afforded by technology.

Accessing data is currently hailed as the key to address many developmental challenges. It has been promoted by influential organizations like the United Nations and the World Bank (Reilly \& Smith, 2013). If data is an asset, governments are among the richest stakeholders, though they face 
challenges to extract value from data, especially in developing countries. Consequently, governments began to publish data assuming citizens could be partners in identifying problems and contributing to finding solutions. These policies had the alleged added benefit of improving the legitimacy of states by increasing transparency and rebuilding trust from citizens.

In 2011, the Open Government Partnership (OGP), an international alliance, began encouraging openness in government interactions. This network of more than 70 member countries has emphasized the implementation of technological tools to increase citizen engagement, fight corruption, and strengthen accountability mechanisms. In this context, open government data (OGD) provision has been promoted as a pivotal reform. However, doubts have been cast on its expected outcomes (Scrollini \& Durand-Ochoa, 2015). In countries like Paraguay, infamous for pervasive corruption, OGD reforms were welcomed. Early after its accession to the OGP, Paraguay published key datasets from strategic sectors such as education, procurement, and healthcare. However, impunity has remained a challenge.

This research will focus on OGD reforms in the education sector of Paraguay aimed at increasing public information and engagement from citizens to monitor the allocation of resources from a national investment fund. Building on the literature on information and communications technology (ICT)-enabled transparency, it will attempt to show that the provision of OGD does not necessarily lead to a reduction of the information asymmetry between governments and citizens or to an increased potential for downwards accountability, even when ICT tools were created to intermediate OGD to facilitate participation. Instead, it will argue that such ICT-enabled transparency reforms, specifically using OGD, can become transparency façades.

This study interrogates the connection between transparency and accountability (Fox, 2007). It analyzes the claim that downwards government accountability requires engagement in collective action (Peixoto \& Fox, 2017). Similarly, it questions whether technical knowledge and resources are important preconditions for OGD engagement (van Schalkwyk et al., 2015).

\subsection{Research Question}

This research will attempt to expose the importance of considering the relationship between politics, accountability, and technology to critically examine the implementation of technological innovations assumed to improve service delivery and reach accountability through increased citizen engagement. The main research question is: To what extent has open government data led to government downwards accountability and improved service delivery in the education sector of Paraguay?

\subsection{Research Structure}

This research starts with conceptual and theoretical frameworks regarding technology-enabled transparency and accountability along with their criticisms. Then, it provides a case study that compares the implementation of a national investment fund for education infrastructure between two local governments. In the process, the implementation of an OGD-based tool created to facilitate 
citizen monitoring will be assessed. The fund's allocation process will also be analyzed. Next, a discussion will put the case study findings in the context of the literature reviewed and the theory of change adopted. The conclusion will summarize the discussion and main messages of this research.

\section{Literature Review}

\subsection{Good Governance and Technology for Development}

Two major developments coincided in the 1990s: a shift in development thinking towards "good governance" and the emergence of the field of Information and Communication Technologies for Development (ICTD). Late in the 1990s, there was a turn towards so-called "second-generation reforms" for addressing problems of governance, among them fighting corruption (Rodrik, 2007). The new paradigm postulated the link between inappropriate governance and underdevelopment; market reforms could not succeed without governments with effective institutions (Carothers \& Brechenmacher, 2014). In parallel, the internet and the Millennium Development Goals promoted what Heeks (2008) termed Information and Communication Technologies for Development (ICTD) 1.0. Since good governance necessitates "participation, rule of law, transparency, responsiveness, consensus orientation, equity, accountability..." (Work, 2003: 195), governments used ICTs to promote more openness and facilitate citizens' access to information.

Theoretically, in a principal-agent model, transparency reforms can reduce the information asymmetry between citizens (i.e., principals) and policymakers (i.e., agents) for better monitoring from the former over the latter (Corduneanu-Huci et al., 2013). Only then the possibility for accountability exists. Early in the 2000s, the understanding of a "long-route" of accountability lost credibility. This approach relied on citizens' political engagement to pressure politicians and policymakers to, in turn, implement reforms and demand efficient service delivery from government bureaucracies. A "short route" approach that directly connected citizens and government providers to exercise "client power" was used instead (World Bank, 2003). In this case, a direct connection between citizens and front-line bureaucrats would result in accountability. The implementation of ICTs to increase citizen voices, improve transparency, and enhance accountability was sought for said purpose (Wittemyer et al., 2014). Hence, governance was improved with the participation of the governed in the exercise of political and administrative authority (Kauzya, 2003). Consequently, the growth of e-governance in terms of e-administration, e-services, and e-participation sought to increase transparency and accountability through opening governments to citizen feedback (Madon, 2009).

\subsection{Transparency, Accountability, and Technology}

There is broad agreement that transparency and accountability are pivotal to any good governance reform. International aid providers have increasingly prioritized accountability, transparency, participation, and inclusion as a political approach to development (Carothers \& Brechenmacher, 2014). Thus, the relationship between said concepts and the assumptions made about their interaction are relevant to the technological innovations that attempt to improve governance. 
Transparency does not invariably lead to accountability (Fox, 2007; Peixoto, 2013). The assumption that with more information out in the public, markets and public authorities will work better, carries the supposition that the power of shaming can influence behaviour away from corruption. Table 1 portrays the distinction between transparency and accountability, and their relationship.

Table 1: Unpacking the Relationship between Transparency and Accountability

\begin{tabular}{|c|c|c|c|}
\hline \multicolumn{2}{|c|}{ Transparency } & \multicolumn{2}{c|}{ Accountability } \\
\hline Opaque & Clear & Soft & Hard \\
\hline \multicolumn{2}{|c|}{ Dissemination and access to information } & & \\
\hline & Institutional "answerability" & $\begin{array}{c}\text { Sanctions, com- } \\
\text { pensation, and /or } \\
\text { remediation }\end{array}$ \\
\hline
\end{tabular}

Source: Fox (2007: 669).

Opaque and clear transparency can be discerned by the extent of information provision on who does what and who gets what. Next, soft and hard accountability can be distinguished by the "answerability" that is possible with the information available, including the potential for sanctions. It follows that the relationship between transparency and accountability could be understood as a continuum (Fox, 2007: 668):

1) when only access to information is available, an institution might be considered transparent, but not accountable;

2) the pre-requisite for accountability is the ability to sanction; and

3) an in-between station where explanations might be demanded because access to information exists, but it's still short of sanctions.

Focusing specifically on ICT-enabled political will, Peixoto and Fox (2017) develop an analytical framework on the concept of accountability. They distinguish aggregated individual assessments of service provision from collective civic action. The former constitutes user feedback and is associated with upwards accountability, while the latter encourages accountability from service providers and is linked to downwards accountability. Table 2 summarizes this distinction to enable greater precision in the analysis of how ICT platforms trigger public sector responsiveness. Institutional response is thus conceptualized as "a clearly identifiable action taken by government or service providers, following individual or collective input by citizens" (Peixoto \& Fox, 2017: 67). 
Table 2: Primary Causal Mechanisms for Accountability

\begin{tabular}{|c|c|c|c|}
\hline \multicolumn{4}{|c|}{ Primary Causal Mechanism for Accountability } \\
\hline Voice pathway & $\begin{array}{l}\text { Upwards ac- } \\
\text { countability }\end{array}$ & $\begin{array}{l}\text { Downwards ac- } \\
\text { countability }\end{array}$ & $\begin{array}{l}\text { Incentives for ac- } \\
\text { countability }\end{array}$ \\
\hline $\begin{array}{l}\text { Individual user } \\
\text { feedback }\end{array}$ & $\begin{array}{l}\text { From frontline ser- } \\
\text { vice providers to } \\
\text { managers or policy- } \\
\text { makers by identify- } \\
\text { ing problems and } \\
\text { triggering adminis- } \\
\text { trative action }\end{array}$ & & $\begin{array}{l}\text { The incentives for } \\
\text { policymakers to act } \\
\text { on user information } \\
\text { are less clear }\end{array}$ \\
\hline $\begin{array}{l}\text { Collective civic } \\
\text { action }\end{array}$ & & $\begin{array}{l}\text { From public sector to } \\
\text { society, by bringing } \\
\text { external pressure to } \\
\text { bear and raising the } \\
\text { political cost of non- } \\
\text { responsiveness }\end{array}$ & $\begin{array}{l}\text { The potential politi- } \\
\text { cal cost to policy- } \\
\text { makers of not re- } \\
\text { sponding to a pub- } \\
\text { licly visible concern. }\end{array}$ \\
\hline
\end{tabular}

Source: Adapted from Peixoto and Fox (2017: 58).

In this context, institutional answerability is more likely when civil society organizations (CSOs) have the capacity to use existing data to produce information which "permits the construction of the right to accountability" (Fox, 2007: 668) through collective civic action (Peixoto \& Fox, 2017). Indeed, the conceptual link between transparency and accountability is incomplete absent the participation that transforms the former into the possibility for the latter.

\subsection{Open Government and Open Data}

Open government reforms are a relatively recent, yet quickly expanding fashion among governments. The chief tenets of the OGP movement are the promotion of transparency, citizen participation, and accountability, with an emphasis on the implementation of innovative technologies (Open Government Declaration, 2011). Open government increases the availability of information about government activities and supports civic participation; it also performs with high standards of professional integrity by increasing access to new technologies for openness, accountability, public participation, information sharing, and collaboration.

The provision of open data has been a trademark reform advocated by the OGP through commitments within the national action plans (NAP) that each member country submits (Verhulst \& Young, 2017). The most commonly used definition for open data is "data that can be freely used, re-used and redistributed by anyone-subject only, at most, to the requirement to attribute and share alike" (OKI, n.d.). Consequently, the datasets provided by governments that abide by that definition are considered open government data (OGD). 


\subsection{OGD Intermediation for Participation and Accountability}

The technical nature of open data conditions participation to the existence of intermediaries able to "translate" data into comprehensible information. An open data intermediary is an agent, which is "at some point in a data supply chain that incorporates an open dataset, is positioned between two agents in the supply chain, and which facilitates the use of open data that may otherwise not have been the case" (van Schalkwyk et al., 2015: 6). This translation requires capital, which is generally understood as either economic, cultural, or social, but in the context of open data could also be technical. In most cases, intermediaries' technical capital is needed to collect, digitize, clean, edit, or translate data into information.

In terms of OGD, the usual intermediaries are CSOs and the press. Through them, citizens receive the information that enables participation, thus the potential for accountability. ${ }^{1}$ But certain assumptions must materialize for ICTs' intermediation to enable citizen empowerment (Heeks, 2002):

1) Data are made available and transparent.

2) Data are accessed by stakeholders who can assess and transform them into information.

3) Information can be acted upon.

4) Information is used to initiate citizen-government and citizen-citizen dialogue and activism.

5) Government acts based on these processes.

Citizen participation is usually appealing when a critical mass has already been formed and the risk of participation is not high (Bailur \& Gigler, 2014). Through aggregation and multiplication, ICTs encourage participation by creating a perception that power in the (virtual) group can challenge the people in power. However, for intermediation to happen, a level of political freedoms and civil rights must exist (Peixoto, 2013). The assumption is that civil society, the press, or engaged individuals - plus technical skills and resources-exist and can leverage their collective clout. In their absence, it is legitimate to claim OGD has little accountability potential.

Consequently, it could be inferred that OGD-enabled accountability requires two conditions: (i) CSOs have the capital to translate data into information, and (ii) the cost of participation in terms of risk, time, and opportunity is not high for citizens. As a result, we might extrapolate at least four basic prerequisites for OGD-enabled accountability to take place:

1) The government provided data in relevant areas for citizens to seek accountability.

2) There are active CSOs with skills and resources to turn OGD into information.

3) CSOs are capable to engage and mobilize citizens towards collective civic action.

4) Citizens can and are willing to afford the costs of participation.

The use of technology as an accountability tool cannot be successful without integrating concerns about how it facilitates collective action (Bailur \& Gigler, 2014). This resonates with the notion of institutional responsiveness motivated by political costs. Figure 1 illustrates the links from transparency to participation and empowerment, until accountability becomes a possibility. ${ }^{1}$ Given the limited space and scope, this study will not delve deeper into CSOs and press intermediation dy-
namics. 
Figure 1: Questioned Relationships between Empowerment, Participation, Transparency, and Accountability

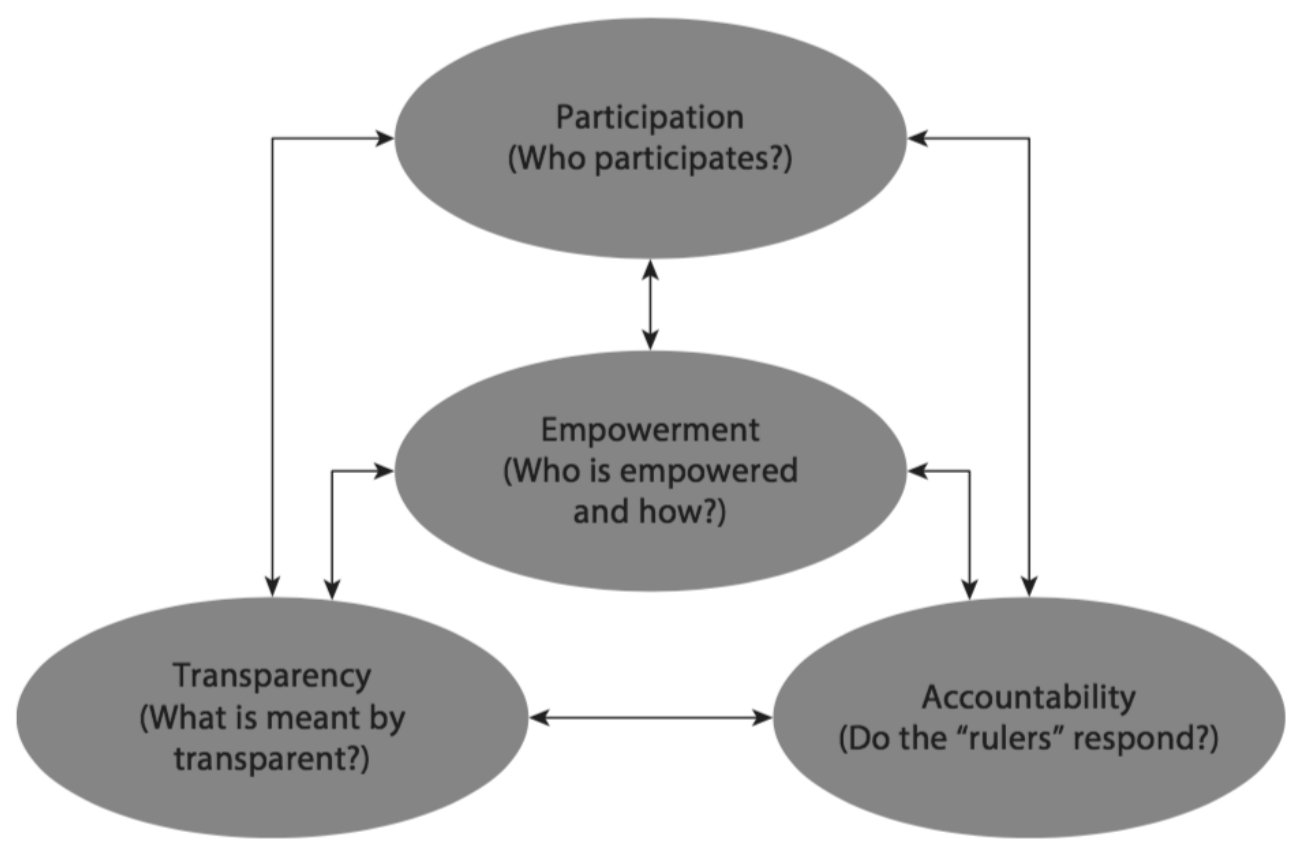

Source: Bailur and Gigler (2014: 10).

Accountability through OGD-enabled participation is complex because it relies on the quality of intermediation - and the capital possessed by intermediaries. In other words, if the implication that governments respond to collective civic action holds, any analysis of OGD's potential for accountability should first interrogate who intermediates participation before trying to find who are the ones participating. ${ }^{2}$

\subsection{Criticisms and Limitations Recognized in the Literature}

As the fields of ICTD and good governance developed in the 1990s, so did an "anticorruption industry" advocating specific types of reforms and promoting attempts to measure progress on governance (Mungiu-Pippidi, 2015). For instance, Transparency International's Global Corruption Barometer (GCB) and Corruption Perceptions Index (CPI), and the World Bank's Worldwide Governance Indicators (WGI), the Global Integrity Index (GII), to cite a few, became rankings that afforded enhanced reputation to countries enacting the standard reforms favored by this industry.

Anticorruption reforms have included enacting freedom of information legislation, the creation of anticorruption agencies, and the establishment of the office of ombudsman. These policy recommendations were based on copying the formal institutions of exemplary governance countries such as Denmark, leading to a degree of "monocropping" that was advocated by multilateral institutions

${ }^{2}$ The challenges of collective action have literature of their own. They go beyond the scope of this document. 
and international civil society organizations. However, bivariate regressions of these interventions found none of them had positive significant effects on control of corruption (Mungiu-Pippidi, 2015).

Currently, there is renewed interest in the long-route of accountability and efforts on previously avoided topics such as power and politics. Indeed, the World Development Report 2004 "inadvertently contributed to popularizing the idea that politics can be bypassed when it is a problem" (World Bank, 2016a: 214). Even when technology is used to take the short-route of accountability, political incentives shape whether leaders will feel pressured to improve governance (World Bank, 2016b).

A sociological critique of this transparency agenda advances that the assumed relationship between institutional openness and public trust is misleading (Moore, 2018). This agenda disregards what the public might need to know and how they approach and use data. Instead, in current programs "the core responsibility of government agencies is to 'push out' as much data as possible" (Moore, 2018: 11). The implicit assumption is that "discerning citizen-consumers" have the skills and abilities to scrutinize available data. However, in making "anyone" the audience of transparency, there is a risk that "no-one" is served by transparency. In this scenario, "open government is understood as a condition achieved by a state, rather than a two-way relationship between the state and citizens" (Moore, 2018: 5). That is, open governments exist through the actions of the public, not merely because there is access to data or information, which must be intelligible, not only visible.

The conceptualization of citizens as consumers of data aligns with recommendations of the New Public Management movement. However, marketization of service delivery through a minimal state model transforms e-government for good governance into efficiency-enhancing applications to serve customers (Ciborra, 2005). This might contribute to a disregard for existing, functional institutions. For instance, it could forgo local administrative, political, and social intermediaries who provide (or could provide) an interface between the formal and informal structures to ensure development impact (Madon, 2009; Bailur \& Masiero, 2012). Hence, by substitution, governance reforms like OGD might ironically make intermediation and disintermediation coexistent.

Open government and open data reforms have not stopped many countries from enacting measures that curtail freedoms such as public access to information (Vasani, Pavlou, \& Maassen, 2013). CSOs' criticisms and doubts on the promises of open government have increased over the years (Scrollini \& Durand-Ochoa, 2015). Commitments made in many OGP national action plans have at times strayed away from open government definitions and principles (Ramírez-Alujas \& Dassen, 2014). Doubts increase on whether open data can deliver on its expected outcomes, especially the accountability that rids government from impunity (Davies, et al., 2013).

The OGP's Global Mid-Term Review 2017 acknowledged that countries can engage in so-called "open washing," which is the practice of publishing datasets that are not particularly relevant with the intention of appearing open. OGD is appealing due to people's fascination with ICTs even when "it is often not used for public decision-making or to hold officials to account" (MTR, 2017). An open letter to the OGP's Global Steering Committee signed by over 60 CSOs urged setting "clear benchmarks for countries to meet after entry within a set timeframe" (MTR, 2017: 51). New OGP country members might simply make services digital and claim it represents government openness. 
Having OGD available is a fraction of the accountability process (Peixoto, 2013). Most of the barriers to reach accountability are not technology-related, but result from social and political factors. Given the high costs of adopting and implementing ICT initiatives to improve democracy or participation in governance, "elite capture" is a common term in the ICT literature (Bailur \& Gigler, 2014). Consequently, participation might happen only at the elite level, i.e., the same traditional actors being the only ones empowered by new ICT tools, especially given the digital divide challenges (Gurstein, 2011). Hence, if the answer to "who participates?" remains basically unchanged, the ensuing goal of citizen empowerment can be questioned. This becomes a fundamental challenge if ICTenabled collective action is the most effective way to institutional responsiveness.

Lastly, presumptions about the default state of governance have considerable effects on the type of anticorruption interventions that can be successful. On one side, there are particular societies in which there are limited access to services, careers, and resources; diametrically opposed to them are societies where ethical universalism prevails and services are open and accessible to all. Most Western-influenced anticorruption interventions assume ethical universalism to be the default, when in fact in developing countries, corruption "is not a deviation, but rather the norm - with the consequence that norm-infringing anti-corruption instruments had been adopted that failed to promote norm building" (Mungiu-Pippidi, 2015: 208). Therefore, achieving a good governance regime with ethical universalism should be considered a political, not a technical or legal process, with power inequality at the center of analysis.

\subsection{Open Government Data: A Theory of Change}

OGD availability has risen around the world, particularly since 2010 (Gonzalez-Zapata \& Heeks, 2015). The optimist outlook on the outcomes of open data abounds even when the empirical evidence lags and has offered mixed results (Verhulst \& Young, 2017; Peixoto \& Fox, 2017). This could be due to the different theories of change used in the literature. A study by IDRC, the World Wide Web Foundation, and the Berkman Klein Center for Internet and Society at Harvard University found at least thirteen. The present study will rely on the following logic model due to its specific focus on OGD in developing countries (Verhulst \& Young, 2017: 38). Figure 2 illustrates the model.

“Open data (supply), when analyzed and leveraged by both governmental and non-governmental actors (demand), can be used in a variety of ways (actions and outputs), within the parameters established by certain enabling conditions (and disabling factors), to improve government, empower citizens and users, create economic opportunity and/or solve societal problems (impact)." 
Figure 2: Open Data in Developing Economies Logic Model

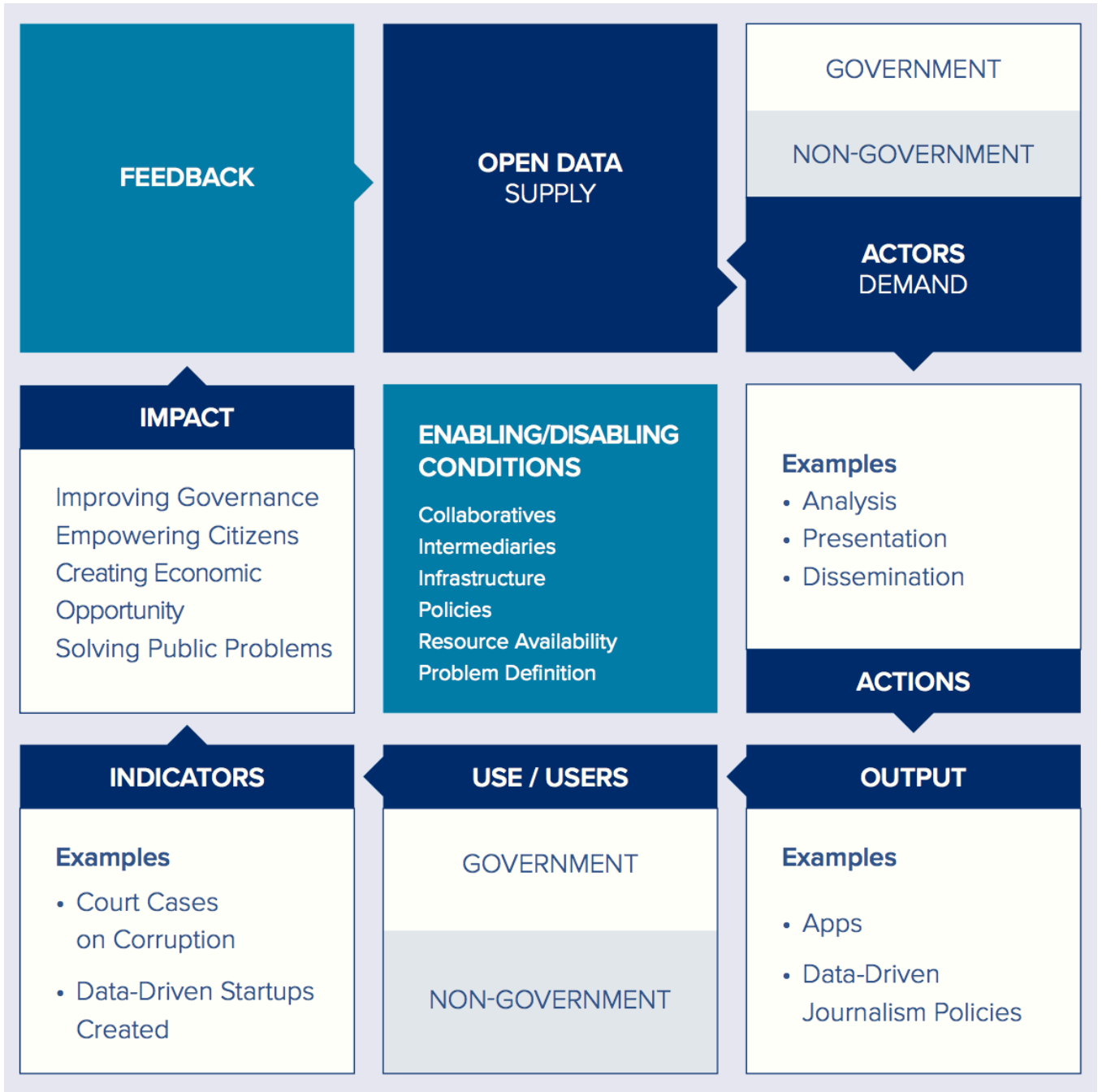

Source: Verhulst \& Young (2017: 39).

\subsection{Contribution to the Literature}

The literature on OGD for accountability is quickly expanding. Verhulst and Young's (2017) systematization of a theory of change for future assessments is a valuable contribution. However, though often critical of superficial reforms, most of the research on OGD impact has focused on technical features, as if politics are less relevant to the success of the reform. This study will attempt to introduce a political explanation to complement the usual technology-centered assessments when it analyzes whether open government data reforms have led to government downwards accountability in the education sector of Paraguay. That is, it will try to integrate political factors to the foundational "context, data, use, and impact" considerations used as a recommended method for open data assessments (Davies, 2014). By introducing politics explicitly, this research will touch upon another lingering question in the literature: "how can ICT-enabled voice platforms become more effective at changing the incentives that influence whether agencies are willing to respond to citizens?" (Peixoto \& Fox, 2017). This search aligns with the beliefs that collective civic action can affect institutional 
responsiveness and that political-centered solutions lead to better governance (Mungiu-Pippidi, 2015).

\section{Research Methodology}

This study will use a qualitative deductive approach to understand whether the implementation of OGD reforms achieved their stated goals of accountability and improved service delivery. A case study research design will be used to analyze the execution of said reforms on Paraguay's National Public Investment Fund for Development (FONACIDE). The application of OGD to FONACIDE will be the unit of analysis. This research design is appropriate due to its ideographic approach by elucidating unique features of the case (Bryman, 2012).

The period reviewed will go from 2015 to 2017 to ensure data availability. This timeframe is ideal for various reasons. First, the Freedom of Information Act (FOIA) was enacted in 2014 and enforced a year later. Second, 2015 was an electoral year for 250 municipalities across the country. Hence, this period minimizes interruptions in procurement processes related to change in administrations. Third, 2015 marks a year since the Ministry of Education and Sciences (MEC) and the Directorate for Public Procurement's (DNCP) datasets and tools were presented with the stated objective of intermediating participation, so citizens could monitor and demand accountability (SENATICS, 2015).

Through purposive sampling, the case study compared the execution of FONACIDE resources in two local governments to assess the impact of the reforms vis-à-vis the theoretical frameworks discussed in the literature reviewed. Moreover, precedents of collective civic action focused on FONACIDE and proximity to the MEC headquarters were used as variables to explain potential differences in outcomes. Additionally, Google Analytics reports for the period July 2015 to July 2018 provided by the National Secretariat for Information and Communication Technologies (SENATICS) were used to check web traffic location for the MEC'S OGD tool. Access to Information formal requests were made to seek unavailable data. Analysis was carried out on OGD from the MEC, the DNCP, and the Finance Ministry. OGP's Independent Review Mechanism's (IRM) and government's reports on National Action Plans were reviewed.

Government downwards accountability was thus measured by responses from MEC or the local government redressing irregularities exposed through collective civic action using OGD. Improved service delivery was evidenced by matching datasets from the MEC and the DNCP in the selected timeframe to check whether resources went to schools within the highest prioritization positions (i.e., the top five).

\subsection{Limitations}

The limitations to this research design and its methods relate to the comprehensiveness of variables considered, data limitations, the validity of proxies, and the absence of interviews with key stakeholders to complement the data analyzed. Namely, Google Analytic metrics are poor proxies for engagement, though there is evidence of their being previously used to evaluate service delivery (Crutzen, et al., 2013). However, given that, to date, the government has not evaluated the MEC's 
OGD-based application, these are the only available data on the subject. Using OGD to evaluate OGD reforms is not common and the strength of this approach might be questioned. However, absent formal evaluations, distilling objectives from relevant legislation and using OGD to check whether they were achieved is a novel contribution to the literature and to the government's understanding of the policy's impact.

Stakeholder analysis of the OGD reforms in the education sector would increase the legitimacy and richness of this research. However, the focus of this study might also profit from a contextualized analysis of the data. To balance this trade-off, this study exploits the fact that this OGD reform was implemented as a government commitment to the OGP. Thus, there exists government selfassessments and the OGP's IRM report on the level of compliance with the commitment, both of which have input from stakeholders.

Finally, this study could have used an evaluation research approach, given its data-analysis component (Bryman, 2012). However, there are no control groups due to the universal nature of the interventions. The fact that the FONACIDE law set allocation criteria and that these resources were distributed to identifiable units for three years before the implementation of OGD-based tools could allow for a differences-in-differences research design to measure the impact of the OGD reforms in the education sector. Nevertheless, the digitization, data cleaning, and formatting efforts would require months. Additionally, disaggregated data at the municipal level is unavailable for many potential control variables. Consequently, if variation was found between the two local governments, it would be difficult to claim whether this was a general trend, a coincidence, or something else.

This study is thus an attempt to establish the foundations for a more sophisticated, mixed-methods design to evaluate the impact of OGD to monitor hundreds of millions of dollars from FONACIDE disbursed to local governments.

\section{Case study: Paraguay's Open Government Reforms in the Education Sector}

\subsection{Why Paraguay and Open Government in the Education Sector?}

Paraguay has recently achieved upper-middle-income status (World Bank, 2015). In Latin America, it consistently ranked poorly in terms of governance and corruption (Transparency International, 2017). However, upon accession to the OGP in 2011, the country has implemented transparency reforms with strong OGD components. Arguably, this led to noteworthy progress in transparency rankings and open data indexes. Additionally, access to the internet has risen to almost $90 \%$ of the population, of which $98.5 \%$ do so through smartphones (SENATICS, 2017).

This study's focus on OGD developments in the education sector has two main reasons. First, it relates to a precarious system that is among the worst in the world in achievements and infrastructure (TERCE, 2015). Second, unlike other OGD reforms in the country, the education sector's technological innovations require the connection of a variety of datasets from more than one government 
ministry. A critical understanding of the reasons for failure are potentially valuable for more than one public agency.

\subsection{The National Public Investment Fund for Development (FONACIDE)}

To fully grasp the implementation of open government data in the education sector, it is first necessary to understand the policy which transparency and accountability it aimed to improve. In 2012, Paraguay achieved a landmark diplomatic deal with Brazil to triple the amount the latter paid for the electrical energy it consumed from the Itaipu Dam, a binational powerplant co-owned by both countries (Itaipu, 2011). Famous journalists and activists started a campaign to secure the excess revenue-estimated at USD 360 million annually -into an investment fund that would be directed to the education sector (ABC Color, 2012).

A long debate ensued as a draft bill structured the allocation of the fund, the agencies that would administer it, and the key actors that would implement its projects; whether the fund would be centrally administered or decentralized to local governments (i.e., distributed to 17 departments and over 250 municipalities) was a central question. The bill passed by congress decentralized its allocation. Different percentages were assigned to fund research, healthcare, education, and other development priorities. From the total, 25\% (i.e., around USD 90 million) was allocated for investment in the education sector and a mandatory $50 \%$ of this amount to be exclusively spent on education infrastructure. Table 3 summarizes the structure of the fund's allocations.

Table 3. Allocation for the FONACIDE Resources According to Sector

\begin{tabular}{|l|l|}
\hline \multicolumn{2}{|c|}{ FONACIDE } \\
\hline Fund for Excellence in Education and Research & $30 \%$ \\
\hline National Treasury & $28 \%$ \\
\hline Local governments & $25 \%$ \\
\hline National Fund for Healthcare & $10 \%$ \\
\hline Financial Development Agency & $7 \%$ \\
\hline
\end{tabular}

Source: Law 4758/2012.

Municipal governments are privileged with $80 \%$ of the resources for education. Local governments receive different amounts according to criteria established in the law. The local governments oversee procurement and monitoring of investments in school infrastructure and lunches financed by the fund. However, by constitutional provision, only the Ministry of Education and Sciences (MEC) can direct education-related policies. Hence, though financial resources were decentralized to local governments, fundamental aspects of the policy implementation were within the MEC's mandate.

Resources for education infrastructure must go to schools that had been prioritized by the MEC through a procedure known as "microplanning" (MEC, 2014). This procedure had been implemented since 2008 and it could be summarized as the community-led (i.e., teachers, parents, associations, and students) identification of needs in every public school. Through layers of aggregation, these lists of infrastructure needs are prioritized by the municipal governments in cooperation with 
technical representatives from the MEC, which consolidate them at the departmental and then ministerial level. This produces an annual comprehensive list of schools in the country, disaggregated at the city level and ranked by priority in terms of infrastructure needs. FONACIDE's law established these prioritization lists as guides for the use of its resources. Only three years later-with about USD 270 million in funds already disbursed - these lists became key datasets the government would digitize and publish to increase transparency in the use of the funds.

Figure 3: FONACIDE's Data Flowchart

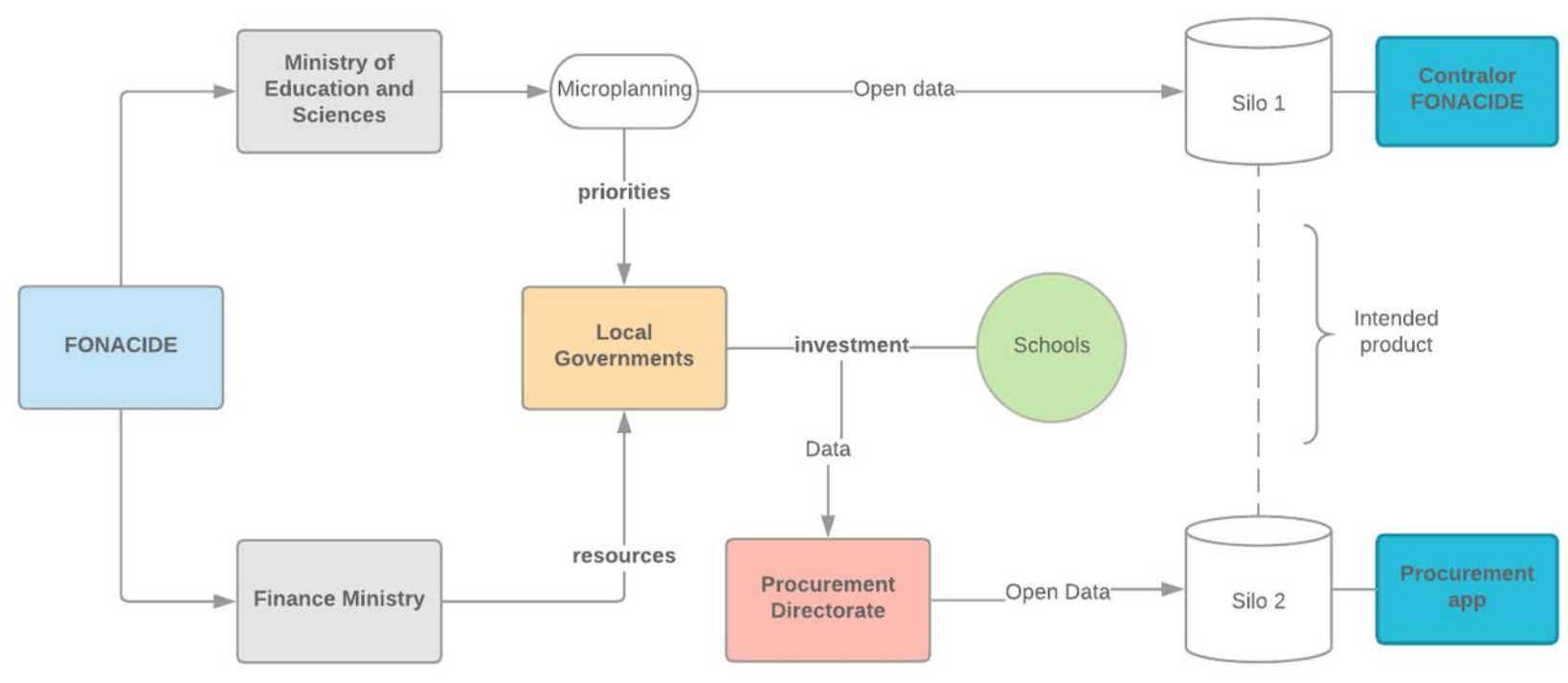

Source: Author's elaboration.

The FONACIDE's labyrinthine administrative process sent resources to hundreds of municipalities, most of which were understaffed and unexperienced in administering such large quantities of money (Figure 3). The process assumed good coordination among two ministries, the procurement directorate, local governments, and local communities connected to the schools. This complexity was evident from the beginning, as was the fact that transparency and monitoring mechanisms were weak (Lovera, 2014).

The monitoring weaknesses relate to the coordination challenges between different government agencies. A major one appears to be the procurement process. The Finance Ministry disburses FONACIDE resources according to vague criteria. ${ }^{3}$ Municipal governments have special bank accounts for FONACIDE and are the ones responsible for the planning stage of the contracting process. Hence, municipalities are also responsible for using the prioritization lists to guide which schools should receive FONACIDE resources. Though the entire process must go through the DNCP, this institution does not own or have a responsibility to check whether prioritization lists were followed by municipalities. This means that contracts awarded with FONACIDE resources ultimately follow

\footnotetext{
${ }^{3}$ The law prioritizes school demographics and location in relation to the Itaipu Dam; those closest to it receive less resources. Allegedly, this happens because the dam already provides royalties to the municipalities affected by its construction.
} 
procurement processes, which does not mean they followed FONACIDE's law in benefiting the neediest schools.

Given the lack of public awareness about FONACIDE's complex administration or the existence of prioritization lists, incentives exist for local politicians to allocate funds wherever they deem convenient; more so when they can claim their procurement processes were fair, though there is evidence that a few schools benefited several times since the fund was created while other, needier ones, never received improvements (Reaccion, 2017) and that political connections have influenced which companies get contracts (Reaccion, 2018).

\subsection{Paraguay and Open Government Data}

The provision of open government data relates to Paraguay's accession to the Open Government Partnership in 2011. The first national action plan 2012-2013 emphasized e-governance reforms in key institutions to improve efficiency within bureaucracies (OGP Paraguay, 2012). This coincided with the adoption of legislation that aimed to improve transparency and anti-corruption measures. However, in 2012, a controversial political crisis ended in the removal of the sitting president before the end of his five-year mandate. Despite the political turmoil, the government self-assessment claimed this did not significantly affect compliance to NAP commitments. However, the IRM assessment noted the consequences of the political episode on the government interaction with civil society (CPP-UCA, 2013). A political outsider won the presidential election in 2013, representing the Colorado Party, historically associated to patrimonialism and corruption.

The new administration pushed for transparency reforms. The next NAP 2014-2016 outlined an ambitious agenda including the adoption of a Freedom of Information Act (FOIA) and the publication of open data portals for key ministries and policies of national scope. Paraguay's FOIA was enacted in the second half of 2014. The law defined the "standards and access mechanisms to public information, regulation of response times and penalties for violations thereof" (OGP Paraguay, 2014). The second commitment of that NAP was the "Design and implementation of an open data policy and promotion [of] capacity building in civil society for its use." FONACIDE, the MEC, and the DNCP were priorities in terms of OGD publication. The SENATICS organized hackathons to engage civil society in the process of reusing the data made available.

Key datasets were published to facilitate monitoring the allocation of FONACIDE resources. This required knowing which schools were eligible to receive FONACIDE funds, their prioritization ranking, and whether procurement processes ended in contracts benefiting said schools, where, and when. The first hackathon awarded winners for the categories, "education" and "public procurement," with the aim to co-develop two apps with ministry specialists that used the recently published datasets. "Contralor FONACIDE" is the name of the application (app) created to facilitate citizen monitoring of the funds.

\subsection{The Contralor FONACIDE Application}

Through the hackathon, the state sought citizen-government interaction facilitated by technology that could improve decision making (SENATICS, 2014). In the education sector, the app's potential 
beneficiaries were schools, contractors, and the educational community. The app had to deliver on the following:

1) Visualizing infrastructure prioritization of eligible schools to receive FONACIDE.

2) Integrating lists detailing different infrastructure needs according to year and school.

3) Link the infrastructure needs (i.e., prioritization) with data from public procurement available in the National Directorate for Public Procurement (DNCP).

4) Including other novel functionalities oriented towards e-governance that are related to infrastructure needs covered by FONACIDE.

Contralor FONACIDE accomplishes all requirements, except linking education OGD with procurement data ${ }^{4}$ (See Figure 3). The app intuitively connects the geolocation of schools with their prioritization ranking in a dynamic map with filter functionalities. Additionally, it provides a summary of the MEC's microplanning procedure, infographics about infrastructure-related data at the national level, and summary graphs about the amount of resources disbursed to municipalities. However, the app's latest available data corresponds to 2015, the year it was launched.

Access to Google Analytics data about the app's website shows concerning results (ATI request, 2018a). Figure 4 contrasts the number of sessions with new visitors. The trend suggests that new visitors have consistently made one-time visits. The average session duration for the entire period covered is 2 minutes and 28 seconds; as the average webpage's session time is 1.83 minutes, it may be implied that visitors did not do much more than look around the website. Moreover, with a rebound rate of $70.42 \%$ from visitors in Paraguay, almost 7 in 10 new visitors did not go beyond the home or landing page of the app. This means users did not even attempt searching for a school or visiting the map that shows eligible schools with their prioritization, the main purpose the app should serve.

${ }^{4}$ The app is available at http://fonacide.mec.gov.py/contralorfonacide/. 
Figure 4: Contralor FONACIDE: Sessions and New Visitors

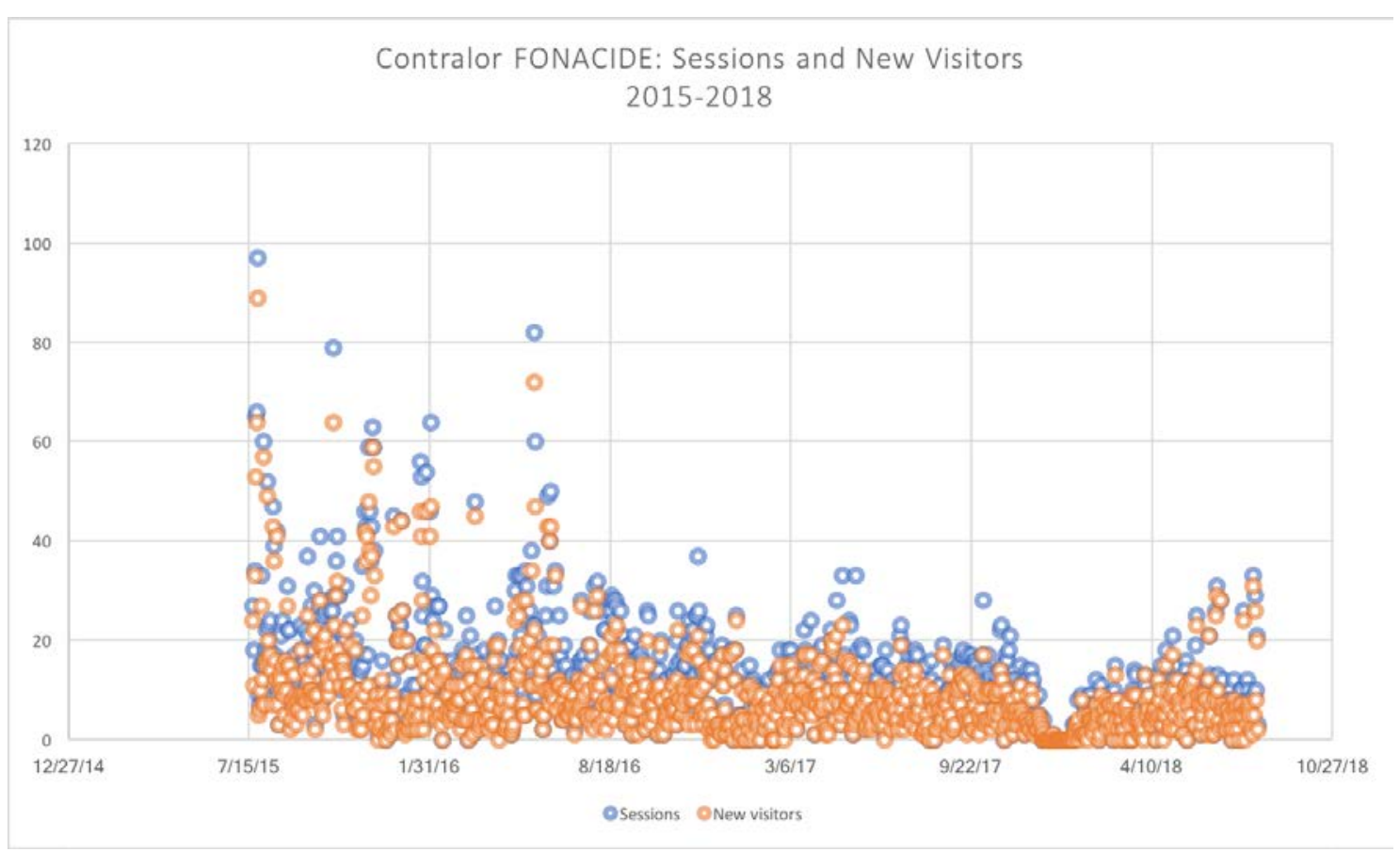

Source: Author's elaboration.

The amount of returning visitors is consistent from the beginning of the app's implementation (Figure 5). The average amount per month is 23.5. It is incorrect to claim this represents any meaningful engagement. It only suggests that a small number of visitors return to the site.

Figure 5: Contralor FONACIDE: Visitors through Time

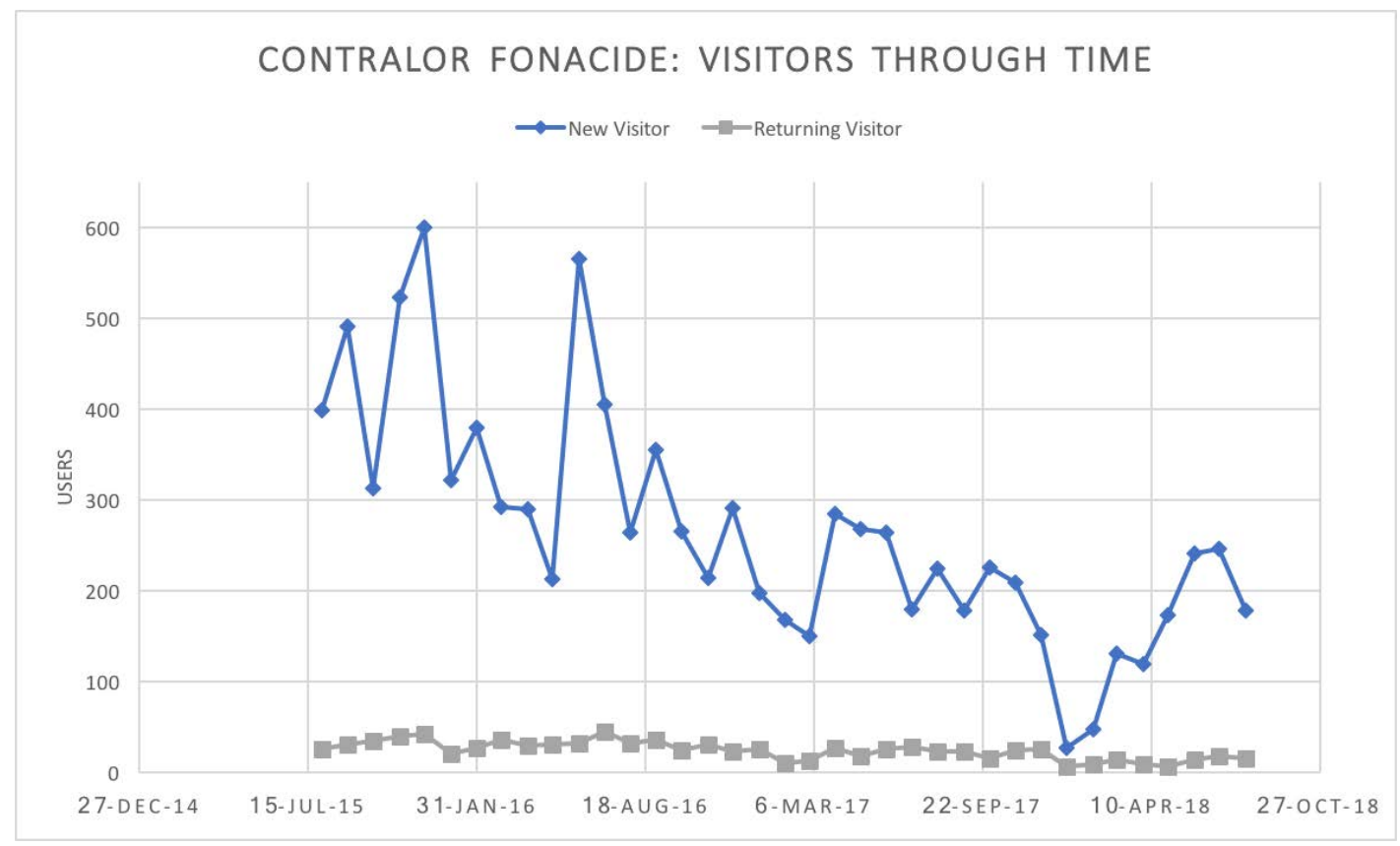

Source: Author's elaboration. 
Over $90 \%$ of visitors to the website are new, indicating that more people are becoming aware of the existence of the website, though few ever return to it (Figure 6). Over half of these new visitors are from Asuncion, the capital, and a remarkable 27\% from abroad. A significant $20 \%$ come from users whose location could not be identified and are labeled "not set" in Figure 7.

Figure 6: Percentage of Visitors to Contralor FONACIDE app
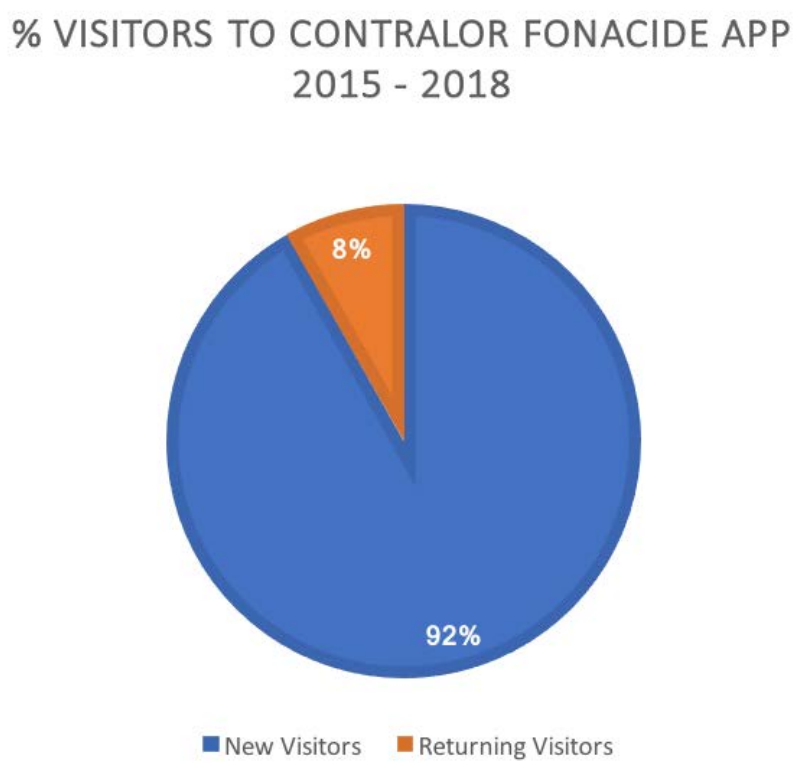

Source: Author's elaboration.

Figure 7: Percentage of New Visitors by Location

\section{$\%$ NEW VISITORS BY LOCATION \\ 2015-2018}

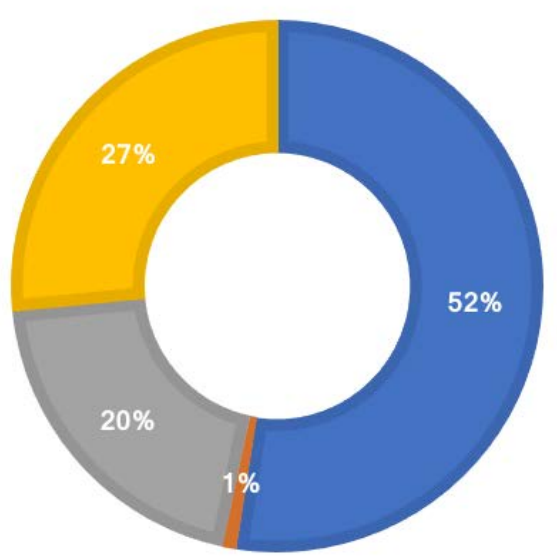

Asuncion

Encarnacion

(not set)

Abroad

Source: Author's elaboration. 
In short, a basic analysis of the app's online traffic data shows it has done poorly on many key indicators. Visitors were mostly from the capital and seldom came back to it or did more than check the first page; people who stayed, seldom used the app's most important monitoring features. This could suggest two things: (1) the app was not promoted adequately by the government or (2) its design and content was not appropriate for the intended users (i.e., citizens).

\subsection{Towards assessing impact of OGD in the education sector}

Tools such as Contralor FONACIDE present OGD more intuitively, so citizens can easily understand and use their content (SENATICS, 2015). However, these tools are simply front-end layers of the open data portals. The portal has a catalog with folders holding XLS spreadsheets for each municipality in the country and its corresponding schools' prioritization lists. But only the datasets for 2015 were facilitated for use. For other years, data is in a format that cannot feed the app, cannot be easily filtered, and requires considerable editions - thus time and technical skills - to turn it into information that is comprehensible to the public. In other words, the open data portal makes its app obsolete by increasing the costs of accessing and using its data.

Although Contralor FONACIDE's potential has been impaired, theoretically there still exists access to data from government in open format. There might be individuals, CSOs, or media that could afford the costs of accessing and transforming the data into information for the public. Assuming that highly interested stakeholders who know about the app would use the open data portal instead, it would be insightful to look at two local governments to assess whether OGD has had measurable impact in terms of downwards accountability and improved service delivery. Using the high number of new visitors as a proxy for the use of the app, the Municipality of Asuncion is a useful case to analyze. It would be convenient to compare it with a municipality of similar size that has had stakeholders using MEC's open data portal. That is the case of the Municipality of Ciudad del Este. Table 4 summarizes other features that make these local governments suitable for comparison in the context of this research.

Table 4: Comparison between Asuncion and Ciudad del Este

\begin{tabular}{|l|l|l|}
\hline \multicolumn{1}{|c|}{ Features } & \multicolumn{2}{c|}{ Municipality } \\
\cline { 2 - 3 } Total amount of $\begin{array}{c}|c| \\
\text { FONACIDE received (USD) }\end{array}$ & $\begin{array}{l}\text { CSD 10.37 million } \\
\text { (2nd in the country) }\end{array}$ & $\begin{array}{c}\text { USD 12.04 million } \\
\left(1^{\text {st }} \text { in the country }\right)\end{array}$ \\
\hline Population size & $\begin{array}{l}529.433 \\
\text { (Largest) }\end{array}$ & $\begin{array}{l}281.422 \\
\left(2^{\text {nd }} \text { Largest }\right)\end{array}$ \\
\hline Civil society ecosystem & $\begin{array}{l}\text { Concentrates the most estab- } \\
\text { lished, well-staffed, and sus- } \\
\text { tainable CSOs in the country }\end{array}$ & \multicolumn{1}{|c|}{ Nascent civil society } \\
\hline $\begin{array}{l}\text { Civil society directly moni- } \\
\text { toring FONACIDE }\end{array}$ & $\begin{array}{l}\text { None that have published } \\
\text { information }\end{array}$ & $\begin{array}{l}\text { One with annual reports on } \\
\text { the use of the funds since } \\
2015\end{array}$ \\
\hline
\end{tabular}




\begin{tabular}{|l|l|l|}
\hline Press / Media outlets & $\begin{array}{l}\text { Three newspapers with na- } \\
\text { tional presence in print and } \\
\text { multi-media platforms } \\
\text { (ABC, UltimaHora, La } \\
\text { Nación); influential online } \\
\text { and alternative news sources }\end{array}$ & $\begin{array}{l}\text { Three newspapers with re- } \\
\text { gional presence in print and } \\
\text { multi-media platforms } \\
\text { (Vanguardia, TnPress, La } \\
\text { Jornada) }\end{array}$ \\
\hline $\begin{array}{l}\text { Collective civic action / fre- } \\
\text { quency }\end{array}$ & $\begin{array}{l}\text { Student mass demonstra- } \\
\text { tions in 2016 led to a govern- } \\
\text { ment-signed commitment to } \\
\text { monitor FONACIDE / inter- } \\
\text { mittent }\end{array}$ & $\begin{array}{l}\text { Grassroots monitoring of } \\
\text { FONACIDE investments } \\
\text { informed by OGD and peti- } \\
\text { tions to the municipal legis- } \\
\text { lative body / 4 years of sus- } \\
\text { tained advocacy }\end{array}$ \\
\hline $\begin{array}{l}\text { Physical proximity from the } \\
\text { MEC headquarters }\end{array}$ & MEC headquarters & 6 hours; Eastern border \\
\hline
\end{tabular}

Sources: DGEEC (2015); Hacienda (2018).

Asuncion and Ciudad del Este are comparable in terms of bureaucratic size and amount of FONACIDE resources received. Being the capital, the former has higher social capital. However, Asuncion has neither a CSO that monitors FONACIDE nor any citizen groups that consistently demand accountability about the fund. Conversely, Ciudad del Este has one CSO, Reaccion, that has consistently published information about FONACIDE for four years while engaging in collective civic action to demand accountability.

Allowing for the assumption that MEC's headquarters holds its best trained bureaucrats, Ciudad del Este's distance from the capital also represents a difference in terms of local institutional capacity to implement and monitor MEC's policies. In this scenario, the literature reviewed would suggest that Asuncion has a higher likelihood of better OGD reform impact on FONACIDE except for Ciudad del Este's sustained collective civic action monitoring the fund.

In the context of FONACIDE, government downwards accountability will be measured by any response from the MEC or the local government redressing irregularities exposed using OGD. Next, improved service delivery will be evidenced by matching datasets from the MEC (prioritization) and the DNCP (contracts) to check whether investment of resources has gone to the top prioritized schools. Figure 8 and 9 illustrate the comparison between service delivery situations in both municipalities for the period 2015-2017. 
Figure 8: Asuncion: Schools Benefited by FONACIDE

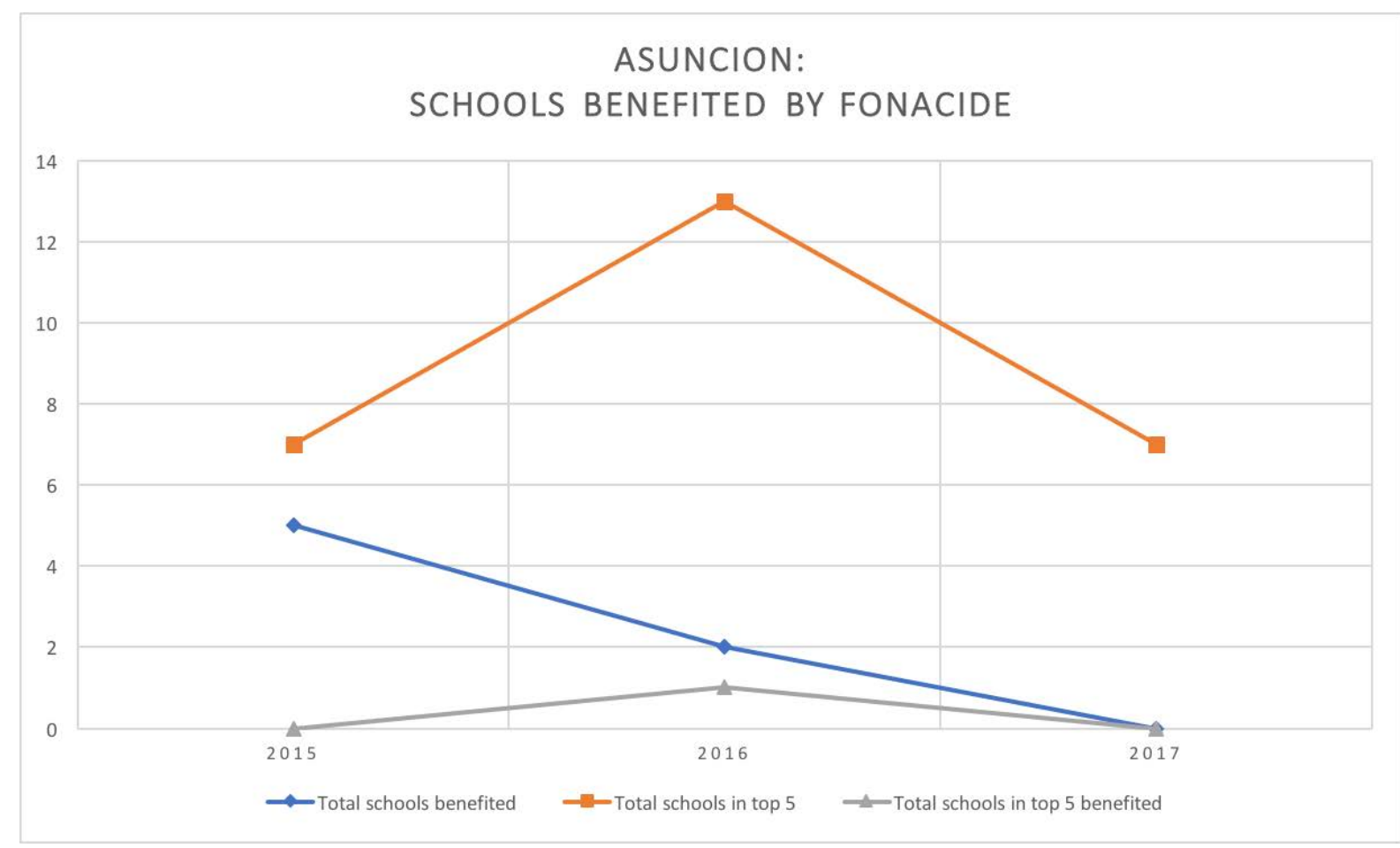

Source: Author's elaboration.

Figure 9: Ciudad del Este: Schools Benefited by FONACIDE

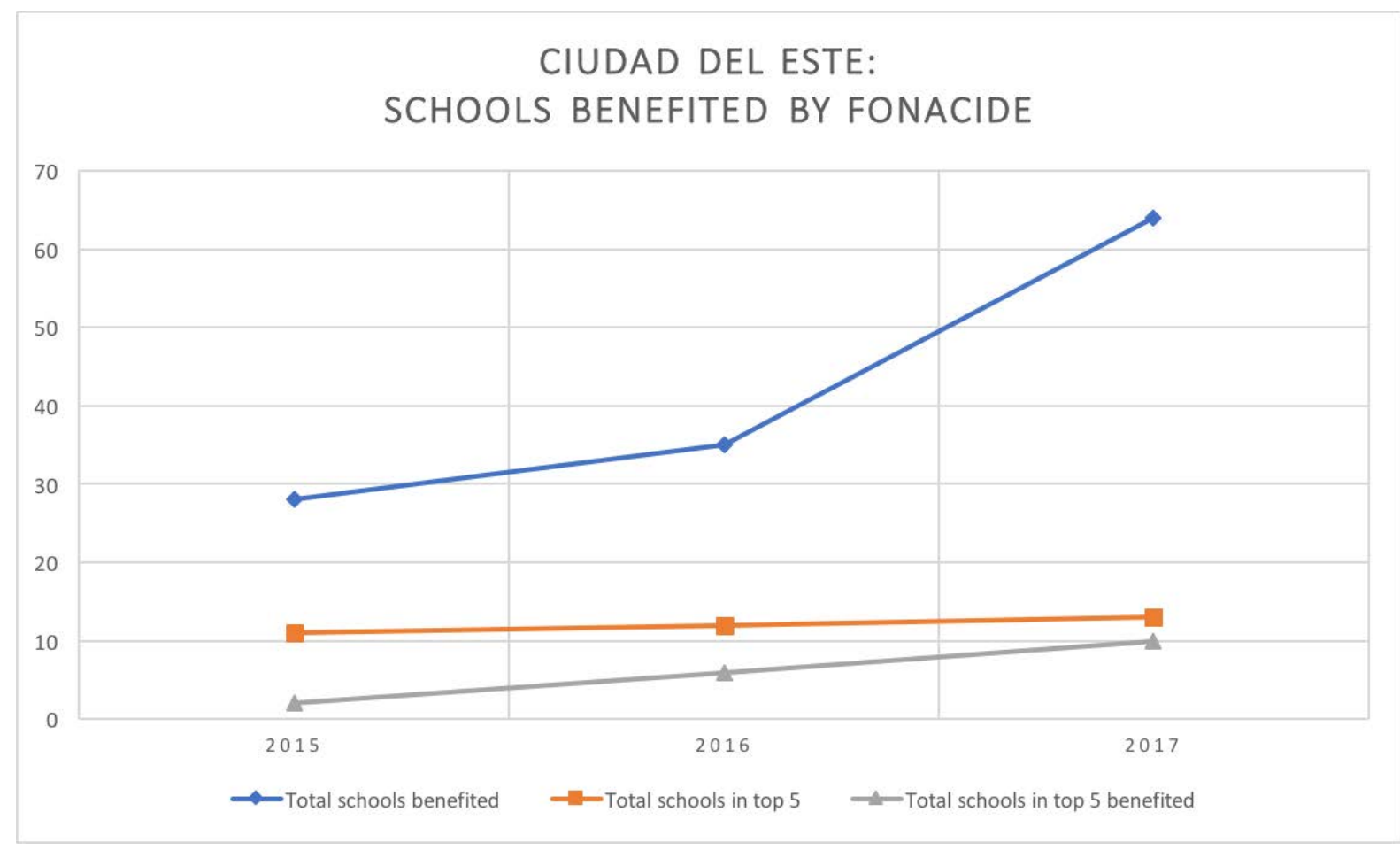

Source: Author's elaboration with datasets provided by Reaccion (2017). 
The Municipality of Asuncion has had less interventions in three years than the Municipality of Ciudad del Este in 2015. In that time, Asuncion has only used FONACIDE to benefit one school with infrastructure investment. Although it is the second municipality with the highest amount of funds received, its execution is small.

In turn, the Municipality of Ciudad del Este has steadily increased the amount of schools benefited by FONACIDE. Noticeably, the number of schools in the top five of the prioritization list has also increased with time and almost matches the total of schools in that ranking for year 2017. The increase in total schools benefited might be one explanation. However, the number of total beneficiaries roughly doubled from 2015 to 2017, while the number of schools in the top five benefiting from the funds increased by a factor of five. Considering that the total number of schools in that ranking barely changed in that period, this might suggest impact from the OGD-informed collective action that took place in Ciudad del Este throughout this time. As such, it might suggest institutional responsiveness because of the public pressure based on the OGD information used by the CSO as the political cost of inaction increased. Indeed, Reaccion's annual reports demonstrate the CSO has the skills and resources to transform OGD into relevant information and focus on community organization in its activities related to FONACIDE (Reaccion, 2015; 2016; 2017).

Regarding downwards accountability, it is difficult to identify any attempts made in Asuncion. The absence of sustained collective civic action to demand accountability about the investments in infrastructure indirectly means institutional responsiveness has not been triggered. In Ciudad del Este, Reaccion documented direct engagement with MEC officials, including the Minister of Education, which was formally ignored (Reaccion, 2017). Moreover, it documented a disinformation campaign led by the local government, which accused the CSO of promoting fake news and serving foreign interests. Though negative, it still qualifies as a response; moreover, even while the local government attempted to delegitimize the CSO, it has nevertheless consistently increased spending in schools within the top five of the prioritization list.

The upshot is that citizens in Asuncion might not know there are many millions of dollars for education infrastructure that have not been spent. Conversely, citizens in Ciudad del Este have benefited from collective action and monitoring of the fund.

\section{Discussion}

What could explain the difference in the service delivery outcomes for Asuncion and Ciudad del Este? To what extent has the OGD reform helped or hindered said outcomes?

\subsection{Context}

In 2014, Paraguay enacted legislation related to transparency and anticorruption. The country's FOIA's regulatory decree established that, whenever possible, public information should be provided in open data format. ${ }^{5}$ The same year, the government decreed its National Development Plan

${ }^{5}$ Decree 4064/2015, Article 7. 
2030. A key line of action is efficient and transparent public management (STP, 2014). Also, the government published key datasets from the MEC and the DNCP. The NAP 2016-2018 was the first to be approved by decree. ${ }^{6}$ In 2016, a new presidential decree demanded municipalities post information about FONACIDE online and added enforcement sanctions. ${ }^{7}$ In sum, at least on paper, the political will and leadership to advance open data reforms were present in the period 2014-2018.

\subsection{Data}

The five stars rating system proposed by Tim Berners-Lee is commonly used to assess the technical openness of data (OKI, n.d.). According to that rating, the FONACIDE-related datasets were threestars open data, which means they were (1) available on the web under an open license, (2) in form of structured data, and (3) in non-proprietary file format. However, the three-stars data only existed for years 2014 and 2015. ${ }^{8}$ Data for years 2016-2018 are two-star rated; they are available in XLS format and need considerable cleaning to be used. As the source for the OGD tool, the Contralor FONACIDE app suffered from said deficiencies.

Data from the DNCP also varies between one and three-stars. The sole way to know which schools were benefited by FONACIDE is to manually skim through PDF copies. Any data intermediary or user would need to manually digitize the name of the schools benefited to link them to the MEC dataset. Hence, the interoperability between these two open data portals and the purported goal to link them to monitor FONACIDE is hard to envision. Thus, the quality of the data, while accessible, increases the cost of intermediaries and other users if they seek to use it for monitoring purposes. This resonates with Moore's (2018) inference that governments tend to push out data focusing on accessibility and visibility, instead of intelligibility and ease of use.

\subsection{Use}

The Contralor FONACIDE app aimed to facilitate citizen monitoring of FONACIDE resources. The app meant to simplify and contextualize data so that costs in terms of policy knowledge and intelligibility could be reduced. In that sense, this was MEC's OGD-tool performing as data intermediary between FONACIDE and citizens. The app's intended beneficiaries were schools, contractors, and the educational community in general (SENATICS, 2014). If the purpose was transparency and monitoring, these must have been the basic assumptions made by the MEC about the app:

1) Citizens can access the internet and understand the process of microplanning.

2) Any community has at least one interested user or intermediary.

3) Established CSOs can intermediate the use of the app, presuming they fulfill assumption 1.

4) There is little need for technical knowledge on procurement processes. Alternatively, citizens use the procurement app and understand it.

5) Citizens or CSOs can transform data into information and engage in collective action.

6) The Ministry or local governments respond, redress irregularities, or impose sanctions.

\footnotetext{
${ }^{6}$ Decree 5894/ 2016.

${ }^{7}$ Law 5581/2016.

8 The MEC's Open Data Portal is available at: https://datos.mec.gov.py/data.
} 
Ciudad del Este's CSO, Reaccion, was also an intermediary. In its reports, this CSO claims it does not use MEC's Contralor FONACIDE app due to the inconsistencies and outdated character of its data (Reaccion, 2017). The World Bank also documented Reaccion's efforts monitoring FONACIDE in Ciudad del Este (World bank, 2017). The publication focused on how open data facilitated their collective civic action through the years. The World Bank's study suggests the costs incurred by this CSO in terms of data use were high, thus improvements in the technical provision of open government data might increase the impact of similar efforts around the country. This resonates with van Schalkwyk, et al. (2015) regarding the importance of capacity and capital availability for intermediaries. Applying Heeks' (2002) assumptions for ICT-intermediation to enable citizen empowerment, we can see the distinction lies on how OGD-based information was used (Table 5). This could suggest that, while using OGD, Reaccion achieved what Bailur and Gigler (2014) believe are important factors for citizen participation to be appealing. Namely, Reaccion could have steadily encouraged the formation of a critical mass and reduced the risks and costs of participation.

Table 5: Potential for ICT-intermediation in Asuncion and Ciudad del Este

\begin{tabular}{|l|c|c|}
\hline \multicolumn{1}{|c|}{ Assumptions } & Asuncion & Ciudad del Este \\
\hline Data is available and transparent & Yes & Yes \\
\hline $\begin{array}{l}\text { Data is accessed by stakeholders who can assess } \\
\text { it and transform it into information }\end{array}$ & $\begin{array}{c}\text { Yes } \\
\text { (Press) }\end{array}$ & $\begin{array}{c}\text { Yes } \\
\text { (Press and CSO) }\end{array}$ \\
\hline Information can be acted upon & Yes & Yes \\
\hline $\begin{array}{l}\text { Information is used to initiate citizen-government } \\
\text { and citizen-citizen dialogue and activism }\end{array}$ & No & $\begin{array}{c}\text { Yes } \\
\text { (sustained collec- } \\
\text { tive civic action) }\end{array}$ \\
\hline Government acts based on these processes & No & Yes \\
\hline
\end{tabular}

Source: Author's elaboration based on Heeks (2002).

\subsection{Impact}

To date, the MEC has not evaluated its OGD tool's impact. The ministry did not establish objectives or progress indicators for said purpose (ATI request, 2018b). Hence, this is the first empirical assessment of the Contralor FONACIDE and its data source. Even the NAP 2014-2016 end-of-term selfassessment from the government only goes as far as describing the datasets offered in MEC's open data portal and the features of Contralor FONACIDE. In fact, it misleadingly claims that linking the lists of prioritized schools with data from public procurement was achieved (OGP Report, 2016: 24). On education OGD and Contralor FONACIDE, the IRM Progress Report 2014-2015, which interviews stakeholders and evaluates OGP commitments' compliance level, suggested improving the app and looking for resources that could help civil society's effort to monitor FONACIDE (CPPUCA, 2015). The fact that procurement data was not linked to monitor investments seems to have been neglected both by the government and the IRM report.

Hypothetically, had the data been kept up to date, citizen reports would still have had little impact. Peixoto and Fox (2017) claim the need that complaints be directed to agencies that have the incentive and capacity to respond. The MEC is not the appropriate agency to respond to complaints because, though it collects and publishes the key datasets for effective service delivery, it is not the 
one to do the procurement processes (see Figure 3 for reference). It is unreasonable to assume that the MEC would receive reports and act upon them by contacting municipal governments to request that funds be allocated differently.

Additionally, the approach taken by creating the app might have bypassed the need for the MEC's technical staff to master the intricacies related to FONACIDE's allocation. Perhaps an attempt to make information provision more efficient led to disintermediation at the micro-level. More specifically, the MEC might have missed the opportunity to rely on their own employees to intermediate between the technology and the people in the schools. As a plausible hypothetical, this would reinforce the need to analyze the effects that technology-based interventions could have on traditional intermediaries before they are implemented (Madon, 2009).

Education OGD and the Contralor FONACIDE app have little claim on achieving their goals. A tool with great potential was crippled by lack of data updates, inexistence of strategies to make the app relevant, missed opportunities to engage existing intermediaries within the ministry, and inappropriate assumptions about engagement and responsibilities in terms of institutional response. Downwards accountability seems theoretically unlikely, as does any improvements in service delivery. But then, what explains the apparent basic improvements in both areas in the Municipality of Ciudad del Este?

Considering the theory reviewed, a look back to Table 4 and Figures 8 and 9 would most likely indicate that Asuncion had higher chances to experience positive impact from the OGD reforms. Its closeness to the central government and the landmark achievement of students regarding FONACIDE were auspicious signs. Hypothetically, this interrogates the pre-requisite of technical capital for OGD intermediation and assigns heavier weight to collective civic action and community work as an explanatory variable. Thus, it supports Peixoto and Fox's (2017) proposition that only civic collective action brings institutional responsiveness.

Alternatively, the case of Ciudad del Este poses doubt on whether an updated, procurementlinked Contralor FONACIDE would eventually lead to institutional responsiveness and downwards accountability. Presumably, it would bring down the costs of monitoring, but it would still do little to ease intelligibility of the complex FONACIDE allocation procedure. Moreover, even if reports were made through the app - amounting to user feedback - if these are not publicly available, they would be weak pressure for institutional response. Additionally, if the MEC remains as the recipient of user feedback, there is little logic in believing it would, first and foremost, contact local governments with requests or that local governments would follow up on those requests.

The civil society advocacy in Ciudad del Este might suggest that technological innovation is the variable with less explanatory potential for transparency and accountability. Theoretically, the CSO could have accessed the XLS sheets about prioritized schools and obtained PDFs through Access to Information (ATI) formal requests without ever using the Contralor FONACIDE app. The explanation for their success seems to be political, rather than technical, as suggested by Mungiu-Pippidi's (2015) theory. It is political to the extent that it results from sustained collective action from an identifiable group of stakeholders, students. 


\subsection{Politics}

A quantifiable impact for the OGD reforms appears elsewhere. In the period 2014-2018, Paraguay improved its ranking both in the CPI (see Figure 10) and the Global Open Data Index (GODI). In 2015, Paraguay ranked 50 th out of 90 countries in GODI; in 2018, it ranked 30th (OGP Paraguay, 2018). Between 2014 and 2015, there was consistent political support in terms of legislation and planning. This might have been enough signaling for international organizations. In that sense, this echoes Mungiu-Pippidi's (2015) finding: institutional monocropping in lines with the anticorruption industry are quickly implemented and provide fast reputational dividends, though the reforms are seldom deepened.

Figure 10: Paraguay's CPI Ranking 2013-2017

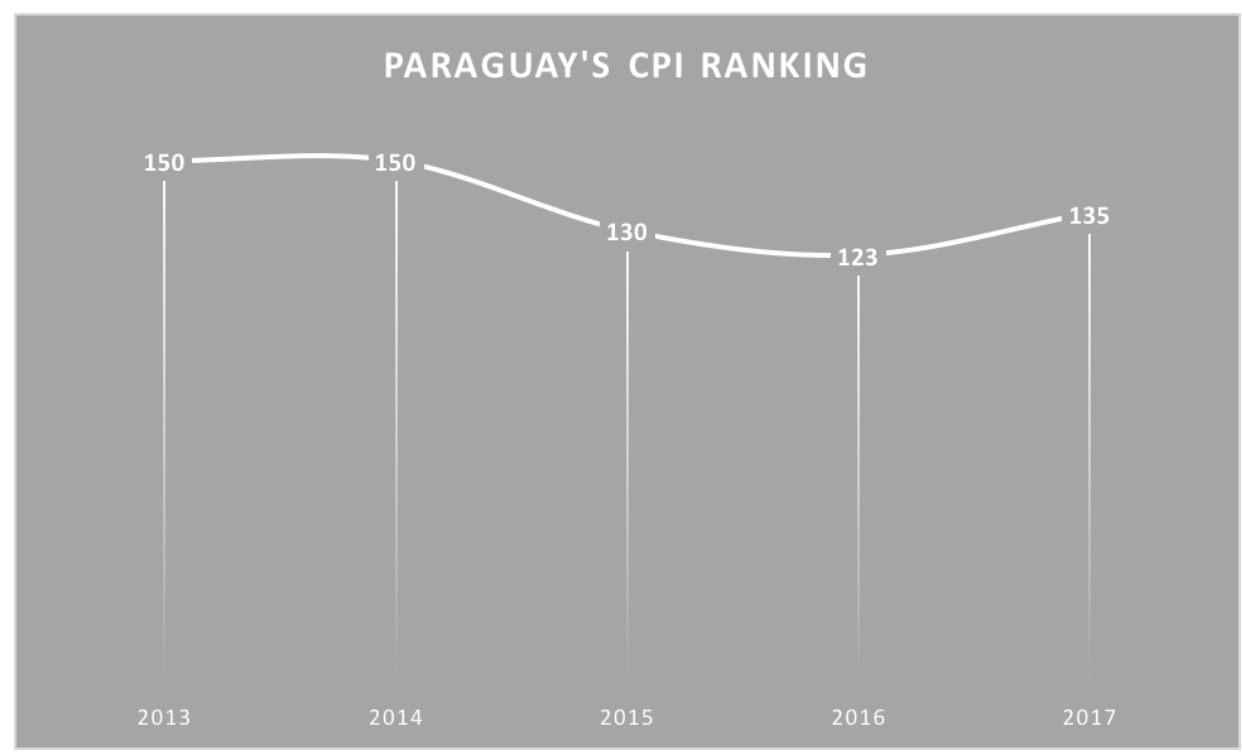

Source: Transparency International (2017)

Thought-provoking developments are found in Paraguay's NAP 2016-2018. Commitments were made to create new open data portals and expand the datasets of existing ones (OGP Paraguay, 2016). Although there is mention of strengthening skills for OGD intermediaries (Commitment 2), nowhere is a hint towards maintaining, updating, or evaluating portals and apps. Commitment 8 concentrates on education; it proposes to expand the portal's number of datasets that feed the Contralor FONACIDE; it once again mentions linking the app to procurement data and it envisions the creation of a mobile interface. Moreover, it includes the conception of yet another new mobile application based on the portal's datasets. There is no mention of updating Contralor FONACIDE's data.

The MEC did not have any theory of change that guided its OGD reform implementation. It assumed that open data supply intermediated by an ICT tool for citizens would lead to transparency and accountability of FONACIDE. It does not seem like enabling conditions were considered, particularly for intermediaries. Indicators were similarly absent, so impact could not be measured and feedback had limited opportunities to be data-based. Through their logical model for OGD, Verhulst and Young (2017) stressed the need of metrics if scaling and replication are sought. But the MEC has 
never assessed its OGD environment, so it is unlikely that documentation for learning has been made. Still, two mobile apps are to be created and more datasets added, though the evidence shows the MEC has not been able to keep one fully functional. Assumptions about tech-mediated citizen participation seem unchallenged and unquestioned.

Worthy of reemphasis is the reiteration of a commitment claiming that procurement data will be now linked. A defense against this failure could be technical limitations. But this new NAP commitment suggests this has been feasible. Then, why has it not been implemented in the past three years? It is reasonable to suggest that a political explanation for this technical failure is appropriate. The first indication is that this commitment has been late; it should have concluded mid-2018 (OGP Paraguay, 2016). The second is the MEC's statement on the subject: "in relation to the app Contralor FONACIDE, goals established in the NAP 2016-2018 were not met due to lack of funds, but they shall resume in the period 2018-2019" (ATI request, 2018b).

In April 2018, Paraguay's Finance Minister was invited by the IMF to talk about the positive effects of the country's transparency reforms. The Minister emphasized that the administration had paid a considerable political cost to move ahead with transparency (IMF, 2018). The evidence for this is hard to find.

A different logic appears to be at play. Namely, a political outsider was elected president in 2013 on a transparency mandate. Though in the past, the president's party had resisted transparency reforms, upon election he pushed it to pass legislation to materialize his repeated claim: "that which is public must be made public." FOIA legislation, advocated for about a decade by CSOs, was finally enacted. Nevertheless, the implementation of the reform tells a different story, one in which the legislation's promising statements met policy that sabotaged its most basic objectives. For instance, important datasets were never updated after the OGD tool was published. Additionally, the OGD reform was set to fail by design; it could not realistically achieve accountability and there is no evidence the government was interested in measuring and evaluating the impact of the policy.

The present case study might be an exemplary case of compromise between the president's public commitments and his need to count on support from his congressmen. Passing legislation and creating transparency tools provided quick reputational benefits nationally and internationally. The administration was applauded for improving its international governance rankings and the political opposition had to recognize this was a step in the right direction. However, power inequality between citizens and government remained unchanged, and potentially corrupt politicians were not at risk of being exposed.

The appropriate implementation of this policy would have ensured procurement processes were made for the neediest schools with active monitoring from citizens. This would have affected the politicians' capacity to spend resources where they pleased. But appropriate implementation was avoided from the onset. For one, the ability to sanction, a pre-requisite for accountability, was assigned to the MEC, which could not enforce it because it had little to do with the procurement process. In fact, upon creation of FONACIDE, the MEC's resources for monitoring infrastructure were considerably reduced, so its capacity to monitor was handicapped just as a colossal amount of resources was about to be invested (ABC, 2013). Another clear evidence is that the MEC never planned 
for an evaluation, despite the hundreds of millions of dollars in infrastructure investment that were at stake. As such, there was no considerable risk that citizens could catch and expose corrupt procedures; their power to demand accountability did not change. Indeed, only in the unlikeliest of cases and at high cost - like in Ciudad del Este-could downwards accountability be achieved.

\section{Conclusions}

This research assessed whether a technology-mediated transparency reform in Paraguay's education sector increased accountability from the government about the National Public Investment Fund for Development (FONACIDE). As a result, this study evidenced the failure of the MEC's open government data reforms. It has amounted to a missed opportunity to intermediate and simplify a truly complex administrative procedure whose efficiency has high developmental value for Paraguay's education sector.

From the onset, the government made unrealistic assumptions about citizen access and use of their technological tool. Tech-facilitated citizen monitoring of the national fund's resources was never a realistic possibility. The tool's usability was crippled by lack of data updates; its effective use required high informational costs to grasp an incredibly complex process; prioritization lists for infrastructure investments in schools were never matched to procurement data; and the institutional recipient of citizen online reports never had the competence or capacity to enforce sanctions. In short, the reforms carried out were technically unviable from the beginning.

Contrasting pertinent open government commitments uncovered a different story, one in which politics provides a better explanation to the technical failures. The contrast between FONACIDE's implementation in two local governments offers additional support to the political nature of the problem, but also a possible solution. The state's incapacity to ensure its tool facilitates collective action did not preclude sustained collective civic action to arise in the unlikeliest of the cases compared, and to have potentially achieved positive impact on service delivery outcomes. While this study has no claims of causality, the comparison shifts protagonism from the technological nature of the solution to both politics and political engagement as explanations for the success or failure of the reform, which is consistent with the literature (Peixoto and Fox, 2017; Mungiu-Pippidi, 2015). Further research should be done using a mixed-methods approach that includes more municipalities, variations of collective civic action, in a longer timeframe with more control variables to have a clearer understanding of what drives improvements in service delivery regarding FONACIDE.

This research has manually analyzed and matched open government data to assess the impact of an open government data reform. The publication of open government datasets is valuable, but does not guarantee accountability (Fox, 2007). OGD needs intermediation capable of translating data into information that is valuable for citizens, but which does not limit itself to that task. It needs intermediation that can also mobilize citizens, so that participation can create the possibility for accountability. Arguably, the government of Paraguay became more transparent while simultaneously precluding any possibility for accountability, yet gaining considerable reputational benefits politically, both at the national and international levels. The international community should be observant of 
countries implementing reforms that look like transparency, claim to increase accountability, but are a simply a façade for both.

\section{References}

ABC Color. (2012). “\#AhoraPy presenta anteproyecto que crea fondo para la educación.” Diario ABC Color. Retrieved from http://www.abc.com.py/edicion-impresa/locales/ahorapy-presenta-anteproyectoque-crea-fondo-para-la-educacion-429234.html

ABC Color. (2013). “El desafío será controlar el uso de los recursos del FONACIDE.” Diario ABC Color. Retrieved from https://www.abc.com.py/especiales/el-pais-que-recibe-cartes/el-desafio-sera-controlarel-uso-de-los-recursos-del-fonacide-609344.html

ATI Request. (2018a). “Solicitud \#14036: Tráfico Web del Contralor FONACIDE." Portal Unificado de Acceso a la Información Pública. Ministerio de Justicia. Retrieved from https:/ /informacionpublica.paraguay.gov.py/portal/\#!/ciudadano/solicitud/14036

ATI Request. (2018b). “Solicitud \#14337: Documentos que establecen la justificación, los objetivos e indicadores utilizados por el MEC para crear y evaluar el uso y progreso de su Portal de Datos Abiertos y su aplicación 'Contralor FONACIDE.'” Portal Unificado de Acceso a la Información Pública. Ministerio de Justicia. Retrieved from https://informacionpublica.paraguay.gov.py/portal/\#!/ciudadano/solicitud/14337

Bailur, S. \& Gigler, B. (2014). "Introduction: The Potential for Empowerment through ICTs" in Gigler, B. and Savita, B. Closing the Feedback Loop: Can Technology Bridge the Accountability Gap? Directions in Development - Public Sector Governance. Washington, DC: The World Bank Group. Retrieved from https:// openknowledge.worldbank.org/handle/10986/18408 License: CC BY 3.0 IGO.

Bailur, S. \& Masiero, S. (2012). The complex position of the intermediary in telecenters and community multimedia centers. Information Technologies \& International Development, 8(1), pp. 27-42.

Bryman, A. (2012). Social Research Methods (Fourth Edition). Oxford University Press.

Carothers, T., \& Brechenmacher, S. (2014). “Accountability, transparency, participation, and inclusion: A New Development Consensus?" Carnegie Endowment for International Peace. Retrieved from https://carnegieendowment.org/files/new_development_consensus.pdf

Ciborra, C. (2005). Interpreting E-Government and Development: Efficiency, transparency or governance at a distance? Information Technology \& People, 18, 3, pp. 260-279.

Corduneanu-Huci, C., Hamilton, A. \& Ferrer, I.M. (2012). Understanding policy change: How to apply political economy concepts in practice. The World Bank. Retrieved from https:/ / openknowledge.worldbank.org/handle/10986/11879 License: CC BY 3.0 IGO.

CPP-UCA. (2013). “Mecanismo de Revisión Independiente: Informe de Avance 2012-2013.” Centro de Políticas Públicas de la Universidad Católica Nuestra Señora de la Asunción. Retrieved from https://www.opengovpartnership.org/sites/default/files/Paraguay_Final_2012_0_0.pdf

CPP-UCA. (2015). “Mecanismo de Revisión Independiente: Informe de Avance 2014-2015.” Centro de Políticas Públicas de la Universidad Católica Nuestra Señora de la Asunción. Retrieved from https://www.opengovpartnership.org/sites/default/files/1-\%20Paraguay_IRM_14-15_Final_0.pdf 
Crutzen, R., Roosjen, J.L., \& Poelman, J. (2013). Using Google Analytics as a process evaluation method for Internet-delivered interventions: an example on sexual health, Health Promotion International, Volume 28, Issue 1, 1 March 2013, Pages 36-42. Retrieved from https://doi.org/10.1093/heapro/das008

Davies, T. (2014). Towards Common Methods for Assessing Open Data. The Web Foundation. Retrieved from https://webfoundation.org/2014/06/towards-common-methods-for-assessing-open-data/

Davies, T., Perini, F., and Alonso, J. M. (2013). “Researching the Emerging Impacts of Open Data: ODDC Conceptual Framework." International Development Research Centre. Retrieved from https:/ /idl-bncidrc.dspacedirect.org/bitstream/handle/10625/56313/IDL-56313.pdf

DGEEC. (2015). “Paraguay Proyección de la Población por Sexo y Edad según Distrito, 2000-2025.” Dirección General de Estadísticas, Encuestas y Censos. Retrieved from http://www.dgeec.gov.py/Publicaciones/Biblioteca/proyeccion\%20nacional/Proyeccion\%20Distrital.pdf

Fox, J. (2007). The Uncertain Relationship between Transparency and Accountability, Development in Practice, 17, 4, pp. 663-671.

Gonzalez-Zapata, F. \& Heeks, R. (2015). The Multiple Meanings of Open Government Data: Understanding different stakeholders and their perspectives, Government Information Quarterly, 32, pp. 441-452.

Gurstein, M. (2011). Open Data: Empowering the empowered or effective data use for everyone? First Monday, 16, 2.

Hacienda. (2018). "Portal de Datos Abiertos." Ministerio de Hacienda. Retrieved from https:// datos.hacienda.gov.py/

Heeks, R. (2002). “I-Development, Not E-Development.” Journal of International Development 14 (1): 1-11.

Heeks, R. (2008). ICT4D 2.0: The Next Phase of Applying ICT for International Development, Computer, 41, 6 , pp. 26-33.

IMF. (2018). "Restoring trust by curbing corruption." International Monetary Fund. Retrieved from http://www.imf.org/external/mmedia/view.aspx?vid=5774745373001

Itaipu. (2011). “Brasil aprobó triplicar compensación al Paraguay por energía de Itaipú." Itaipu Binacional. Retrieved from https://www.itaipu.gov.br/es/sala-de-prensa/noticia/brasil-aprobo-triplicar-compensacion-al-paraguay-por-energia-de-itaipu

Kauzya, J. (2003). “Strengthening Local Governance Capacity for Participation," in Rondinelli, D. A., and Shaabbir Cheema, G. (eds.) Reinventing Government for the Twenty-First Century: State Capacity in a Globalizing Society. USA: Kumarian Press Inc., pp. 181-193.

Lovera, N. (2014). “Tras informe de Comisión Especial, proponen modificar Ley de FONACIDE." Cámara de Senadores de la República del Paraguay. Retrieved from http://www.senado.gov.py/www2/index.php/noticias-2/169308-tras-informe-de-comision-especial-proponen-modificar-ley-de-fonacide2014-04-24-18-49-37

Madon, S. (2009). E-Governance for Development: A focus on rural India. Palgrave Macmillan, Hants, Chapter 4, pp. 53-70. 
MEC. (2014). "Manual de Microplanificación de la Oferta Educativa." Ministerio de Educación y Ciencias. Retrieved from http://fonacide.mec.gov.py/contralorfonacide/static/manual-microplanificacion.pdf

Moore, S. (2018). Towards a Sociology of Institutional Transparency: Openness, Deception and the Problem of Public Trust. Sociology, 52(2), pp.416-430.

MTR. (2017). “Open Government Partnership: Mid-Term Review.” Development Portfolio Management Group. University of Southern California. Retrieved from http://www.opengovpartnership.org/sites/default/files/OGP_MTR-Report_Final-Jan26-2016.pdf

Mungiu-Pippidi, A. (2015). The Quest for Good Governance: How Societies Develop Control of Corruption. Cambridge University Press.

OGP Declaration. (2011). “Open Government Declaration.” Retrieved from https://www.opengovpartnership.org/open-government-declaration

OGP Paraguay. (2012). “Plan de Acción de Gobierno Abierto 2012-2013." Gobierno Abierto Paraguay. Retrieved from https://www.opengovpartnership.org/sites/default/files/legacy_files/country_action_plans/Gobierno\%20Abierto\%20-\%20Plan\%20de\%20Accion\%202012_2.pdf

OGP Paraguay. (2014). “Plan de Acción de Gobierno Abierto 2014-2016." Gobierno Abierto Paraguay. Retrieved from https://www.opengovpartnership.org/sites/default/files/PLAN\%20DE\%20ACCI\%C3\%93N\%20GOBIERNO\%20ABIERTO\%20ingl\%C3\%A9s.pdf

OGP Paraguay. (2016). “Plan de Acción de Gobierno Abierto 2014-2016," Gobierno Abierto Paraguay. Retrieved from https://www.opengovpartnership.org/sites/default/files/PY_NAP3_Eng_0.pdf

OGP Paraguay. (2018). “Posicionan a Paraguay en el puesto 37 de 94 países evaluados en el Índice Global de Datos Abiertos." Gobierno Abierto Paraguay. Retrieved from http://www.gobiernoabierto.gov.py/articulo/posicionan-paraguay-en-el-puesto-37-de-94-pa\%C3\%ADses-evaluados-en-el-\%C3\%ADndiceglobal-de-datos

OGP Report. (2016). “Paraguay: Final Self-Assessment Report 2014-2016.” Gobierno Abierto Paraguay. Retrieved from https://www.opengovpartnership.org/sites/default/files/Paraguay_End-of-Term-SelfAssessment-Report_2014-2016_EN.pdf

OKI. (n.d.). "Five stars of open data" Open Knowledge International. Retrieved from http:/ /opendatahandbook.org/glossary/en/terms/five-stars-of-open-data/

OKI. (n.d.). “What is Open Data?" Open Knowledge International. Retrieved from http:/ /opendatahandbook.org/guide/en/what-is-open-data/

Peixoto, T. (2013). “The Uncertain Relationship Between Open Data and Accountability: A Response to Yu and Robinson's The New Ambiguity of 'Open Government.'” UCLA Law Review. Retrieved from https://www.uclalawreview.org/pdf/discourse/60-14.pdf

Peixoto, T. \& Fox, J. (2017). “When does ICT-enabled voice lead to Government Responsiveness?" in Peixoto, T. \& Sifry, M. L. (eds.) Civic Tech in the Global South: Assessing Technology for the Public Good. Washington, DC: The World Bank Group, pp. 51-94. 
Ramírez-Alujas, A., \& Dassen, N. (2014). "Winds of change: The Progress of Open Government Policymaking in Latin America and the Caribbean." Inter-American Development Bank. Institutions for Development Institutional Capacity of the State Division. Technical Note No. IDB-TN-629.

Reaccion. (2018). “Informe de Monitoreo de Ejecución Física del FONACIDE: Ciudad del Este 2018.” Reacción Paraguay. Retrieved from https://www.reaccion.org.py/informe-mef-cde-2018/

Reaccion. (2017). “Informe de Monitoreo de Ejecución Física del FONACIDE: Ciudad del Este 2017." Reacción Paraguay. Retrieved from https://www.reaccion.org.py/informe-mef-cde-2017/

Reaccion. (2016). "Informe de Monitoreo de Ejecución Física del FONACIDE: Ciudad del Este 2016." Reacción Paraguay. Retrieved from https://www.reaccion.org.py/informe-mef-cde-2016-2/

Reaccion. (2015). “Informe de Monitoreo de Ejecución Física del FONACIDE: Ciudad del Este 2015." Reacción Paraguay. Retrieved from https://www.reaccion.org.py/informe-mef-cde-2015-2/

Reilly, K.M. \& Smith, M.L. (2013). The emergence of open development in a network society. Open development: Networked innovations in international development, pp. 15-50. Retrieved from https://idl-bncidrc.dspacedirect.org/bitstream/handle/10625/52348/IDL-52348.pdf

Rodrik, D. (2007). One Economics, Many Recipes: Globalization, Institutions, and Economic Growth. Princeton University Press.

Scrollini, F. \& Durand-Ochoa, U. (2015). "Perspectives on Open Government in Latin America." LSE Ideas. The London School of Economics and Political Science. Retrieved from http://www.lse.ac.uk/ideas/Assets/Documents/updates/LSE-IDEAS-Open-Government-LatinAmerica.pdf

SENATICS. (2014). “Hackathon 2014: Bases y Condiciones.” Secretaría Nacional de Tecnologías de Información y Comunicación. Retrieved from https://hackathon.innovando.gov.py/application/files/4915/1438/0540/EVENTOINNOVANDOPARAGUAY-version4-12-2014.pdf

SENATICS. (2015). "Presentan aplicaciones que permiten el acceso a datos abiertos del Gobierno." Secretaría Nacional de Tecnologías de Información y Comunicación. Retrieved from https:/ / www.senatics.gov.py/noticias/presentan-aplicaciones-que-permiten-el-acceso-a-datos-abiertos-del-gobierno

SENATICS. (2017). “Encuesta Acceso y Uso de Internet en Paraguay." Secretaría Nacional de Tecnologías de Información y Comunicación. Retrieved from http://gestordocumental.senatics.gov.py/share/s/ntjnuNLeT8u3gbAHC6WeVw

STP. (2014). “Plan Nacional de Desarrollo 2030.” Secretaría Técnica de Planificación del Desarrollo Económico y Social. Retrieved from http://www.stp.gov.py/pnd/wp-content/uploads/2014/12/pnd2030.pdf

TERCE. (2015). “Tercer estudio regional comparativo y explicativo." UNESCO. Retrieved from http:/ / unesdoc.unesco.org/images/0024/002435/243532S.pdf

Transparency International. (2017). "Paraguay: Corruption Perceptions Index 2017." Retrieved from https://www.transparency.org/country/PRY 
Van Schalkwyk, F., Chattapadhyay, S., Caňares, M. \& Andrason, A. (2015). “Open data intermediaries in developing countries." ODDC Vol. 12 No. 2: Special issue on Open Data for Social Change and Sustainable Development. Retrieved from http://ci-journal.org/index.php/ciej/article/view/1146

Vasani D., Pavlou A., \& Maassen, P. (2013). “Improving the OGP Experience." Hivos: The Hague. Retrieved from http://www.ogphub.org/media/ImprovingtheOGPExperience.pdf

Verhulst, S. \& Young, A. (2017). “Open Data in Developing Economies: Toward building an evidence base on what works and how." theGovLab. Retrieved from http://odimpact.org/files/odimpact-developing-economies.pdf

Wittemyer, R., Bailur, S., Anand, N., Park, K., \& Gigler, B. (2014). “New Routes to Governance: A Review of Cases in Participation, Transparency, and Accountability," in Gigler, B. and Savita, B. Closing the Feedback Loop: Can Technology Bridge the Accountability Gap? Directions in Development - Public Sector Governance. Washington, DC: The World Bank Group. Retrieved from https://openknowledge.worldbank.org/handle/10986/18408

Work, R. (2003). “Decentralizing Governance: Participation and Partnership in Service Delivery to the Poor," in Rondinelli, D. A., \& Shaabbir Cheema, G. (eds.) Reinventing Government for the Twenty-First Century: State Capacity in a Globalizing Society. USA: Kumarian Press Inc., pp. 195-218.

World Bank (2016a). Making Politics Work for Development: Harnessing Transparency and Citizen Engagement. Policy Research Report. Washington, DC. Retrieved from https:/ / openknowledge.worldbank.org/handle/10986/24461 License: CC BY 3.0 IGO.

World Bank (2016b). “World Development Report 2016: Digital Dividends.” Washington, DC: World Bank. Retrieved from https://openknowledge.worldbank.org/handle/10986/23347 License: CC BY 3.0 IGO.

World Bank. (2003). World Development Report 2004: Making Services Work for Poor People. The World Bank. Retrieved from https://openknowledge.worldbank.org/handle/10986/5986 License: CC BY 3.0 IGO.

World Bank. (2015). “WB Update Says 10 Countries Move Up in Income Bracket.” The World Bank Group. Retrieved from http://www.worldbank.org/en/news/press-release/2015/07/01/new-world-bankupdate-shows-bangladesh-kenya-myanmar-and-tajikistan-as-middle-income-while-south-sudan-fallsback-to-low-income

World Bank. (2017). “Citizens as Drivers of Change: How Citizens Practice Human Rights to Engage with the State and Promote Transparency and Accountability." Washington, DC: World Bank. Retrieved from https://openknowledge.worldbank.org/handle/10986/27653 License: CC BY 3.0 IGO.

\section{About the Author}

\section{David Riveros García}

David Riveros García is Founder and Executive Director of reAcción Paraguay, an organization that uses civic education, technology, and grassroots mobilization to enable youth to wield power strategically and promote change by demanding accountability from government. He started reAcción at age 18. He was named a Global Changemaker by the British Council and a Youth Ambassador by the US Embassy. He co-founded the Global Youth Anti-Corruption Network and is a board member of the World Youth Movement for Democ- 
racy. He has presented as panelist at events like the World Economic Forum, the International Anti-Corruption Conference, and the Civil Society Policy Forum at the WB-IMF Annual Meetings. His organization's projects were featured in publications by Transparency International, the United Nation's CEPAL, and the World Bank. García has worked as a consultant on citizen engagement, social accountability, and open government for the World Bank and USAID. He led the development of Paraguay's Healthcare Ministry's official open data tool, Akuerapp. David has a Master's in Development Studies as a Chevening Scholar at The London School of Economics and Political Science. He is fluent in four languages: Guaraní, Spanish, Portuguese, and English. 